\title{
Distribution of picophytoplankton and nanophytoplankton along an anthropogenic eutrophication gradient in French Mediterranean coastal lagoons
}

\author{
Béatrice Bec ${ }^{1}$, Yves Collos ${ }^{1, *}$, Philippe Souchu' ${ }^{2,4}$, André Vaquer1, Jacques Lautier ${ }^{1}$, \\ Annie Fiandrino ${ }^{2}$, Laurent Benau ${ }^{2}$, Valérie Orsoni ${ }^{3}$, Thierry Laugier ${ }^{2}$ \\ ${ }^{1}$ Université Montpellier 2, Laboratoire Ecosystèmes Lagunaires, UMR 5119 CNRS-Université Montpellier II-Ifremer, IRD, \\ Place Eugène Bataillon, CC093, 34095, Montpellier Cedex 5, France \\ ${ }^{2}$ Ifremer LER LR, BP 171, Avenue Jean Monnet, 34203 Sète Cedex, France \\ ${ }^{3}$ Ifremer, LER Corse, Zone industrielle de Furiani, 20600 Bastia, France \\ ${ }^{4}$ Present address: Ifremer, LER/MPL/NT, Rue de l'Ile d'Yeu, BP 21105, Nantes, France
}

\begin{abstract}
We explored the role of natural and anthropogenic environmental perturbations in shaping the community structure and dynamics of pico- and nanophytoplankton in coastal waters. The distribution patterns of phycoerythrin-rich picocyanobacteria (PE-CYAN) and phycocyanin-rich picocyanobacteria (PC-CYAN), autotrophic picoeukaryotes (PEUK) and nanophytoplankton (NANO) were examined over a period of $3 \mathrm{yr}$ in 24 Mediterranean coastal lagoons displaying wide trophic gradients (from 0.2 to $630 \mu \mathrm{g}$ chlorophyll $a\left[\mathrm{chl} \mathrm{a} \mathrm{l}^{-1}\right.$ ) and salinity gradients (from fresh to marine waters). In summer, picoplanktonic abundances reached $3 \times 10^{8}$ cells l$^{-1}, 5 \times 10^{9}$ cells l$^{-1}$ and $6 \times 10^{10}$ cells $\mathrm{l}^{-1}$ for PE-CYAN, PC-CYAN and PEUK, respectively. PE-CYAN and PC-CYAN showed opposing responses to environmental gradients, resulting in a restricted dominance of PE-CYAN in oligotrophic marine lagoons and a dominance of PC-CYAN in some eutrophic brackish lagoons. Most lagoons exhibited steady-state nutrient conditions, giving competitive advantages to small eukaryotic algae, even in eutrophic and hypertrophic waters. Among the picophytoplankton, picoeukaryotes (ca. 2 to $3 \mu \mathrm{m}$ ) are the most competitive with increasing nutrient availability; in terms of abundance and biomass, their relative and absolute importance tended to increase with increasing total chl a biomass. Freshwater discharges resulted in large pulses of nutrient and more turbulent systems that altered the structure of the phytoplankton community and stimulated fast-growing NANO composed of phytoflagellates and diatoms (ca. 3 to $6 \mu \mathrm{m}$, up to $1.6 \times 10^{9} \mathrm{cells}^{-1}$ ). Members of the microphytoplankton (ca. 20 to $200 \mu \mathrm{m}$ ) were rarely observed in eutrophic and hypertrophic lagoons and were composed of harmful dinoflagellates in oligotrophic lagoons. These results show that anthropogenic and meteorological changes are highly influential on the composition and size structure of phytoplankton communities.
\end{abstract}

KEY WORDS: Autotrophic picoeukaryotes $\cdot$ Picocyanobacteria $\cdot$ Nanophytoplankton $\cdot$ Abundance Biomass · Eutrophication · Mediterranean lagoons

\section{INTRODUCTION}

In estuarine and coastal ecosystems, community structure and the dynamics of phytoplankton are heavily shaped by a wide variety of environmental parameters, including nutrient inputs, salinity, turbidity and other optical properties of the water column. In these coastal waters, anthropogenic nutrient enrichment and hydrological perturbations related to freshwater discharges are the major stressors that cause significant changes in phytoplankton biomass and in the composition of the community (Phlips et al. 2002, Paerl et al. 
2003, 2006). Freshwater discharges are the main sources of nutrients in coastal waters and they influence multiple hydrologic parameters, such as salinity and water residence time. Residence time plays an important role in determining the availability and utilization of nutrients by phytoplankton (Paerl et al. 2006). It is well known that nutrient availability influences the size structure of the phytoplankton community (Malone 1980, Chisholm 1992). Therefore, changes in phytoplankton community structure, in terms of composition and size, can reflect phytoplankton responses to natural and anthropogenic environmental perturbations.

The size distribution of the phytoplankton community-particularly the partitioning between small phytoplankton (picoplankton and nanoplankton: $<20 \mu \mathrm{m}$ in size) and larger cells - plays an essential role in carbon flux and food webs in pelagic systems (Legendre \& Rassoulzadegan 1995). The abundance and biomass of the picophytoplankton $(\leq 3 \mu \mathrm{m})$ generally increases with trophic status while their relative contribution to total autotrophic biomass declines (Weisse 1993, Agawin et al. 2000, Bell \& Kalff 2001). A thin diffusion boundary layer and a high surface-tovolume ratio, due to small size, confer on picoplanktonic cells a greater capacity to acquire and use nutrients in resource-limited areas - leading to competitive advantages over larger cells in oligotrophic waters (Raven 1986, Chisholm 1992). When nutrient availability increases, the larger phytoplankton could outcompete the picophytoplankton because they are released from the constraints of nutrient diffusion limitation (Agawin et al. 2000). Among the autotrophic picoplankton community, the distribution of prokaryotic and eukaryotic components overlaps along the gradient of a land-sea transect from offshore to nearshore waters. Prochlorococcus (ca. 0.5 to $0.7 \mu \mathrm{m}$ in size) is the dominant genus of picocyanobacteria in offshore nutrient-depleted waters, while Synechococcus (ca. $1 \mu \mathrm{m}$ in size) generally thrives in moderately oligotrophic and mesotrophic waters (Partensky et al. 1999, Gin et al. 2003, Pan et al. 2007). Autotrophic picoeukaryotes (ca. 2 to $3 \mu \mathrm{m}$ in size) show a clear trend in enhanced abundance in coastal waters where they can surpass picocyanobacteria in terms of biomass (Vaquer et al. 1996, Gobler et al. 2002, Calvo-Diaz \& Morán 2006, Pan et al. 2007). These distribution patterns show that the nutrient availability could potentially shape the size structure of the phytoplankton community, even in the picoplanktonic cell range. In addition to nutrients, gradients of salinity and optical properties of the water column (from blue offshore waters to green coastal waters) can also shape the distribution of picoplanktonic organisms in oceanic waters (Morel et al. 1993, Partensky et al. 1999). Hence, picocyanobacteria and picoeukaryotes show differential responses to environ- mental gradients. In particular, it can be hypothesized that the relative importance of prokaryotic and eukaryotic picoplanktonic components could differ in terms of abundance and biomass along the trophic gradient. Given the functional importance of autotrophic picoeukaryotes in microbial food webs and carbon flux in coastal marine waters (Worden et al. 2004, Bec et al. 2005), there is a need to clarify the relative and absolute importance of picocyanobacteria and picoeukaryotes as a function of trophic status, and to examine the main factors that regulate their distribution in coastal systems.

Among coastal zones, lagoons are highly productive and dynamic systems (Kjerfve 1994) but they are particularly sensitive to anthropogenic and climatic perturbations. On the one hand, their restricted water exchanges with the sea, and the potential accumulation of elevated levels of nutrients supplied by watersheds and internal cycling, may amplify the eutrophication processes (Kjerfve 1994, Glibert et al. 2010). On the other hand, due to their location at the land-sea interface, and their shallowness, they exhibit great physical and chemical variability related to natural constraints (e.g. freshwater discharges, wind and tides). All of these environmental perturbations have broad impacts on the patterns of phytoplankton biomass and community composition (Knoppers 1994, Phlips et al. 2002).

Several studies have shown that picophytoplankton can be a major component of phytoplankton communities in coastal lagoons (Sorokin et al. 1996, Vaquer et al. 1996, Phlips et al. 1999). In these systems, it is expected that changes in the structure of the picophytoplankton community could reflect picoplanktonic responses to natural and anthropogenic environmental perturbations. In this context, we investigated the distribution patterns and the size structure of phytoplankton communities with a specific emphasis on picophytoplankton and nanophytoplankton in 24 French Mediterranean lagoons characterized by large trophic gradients (from oligotrophy to massive eutrophication) and salinity gradients (from fresh to marine waters). The objectives of the present study were: (1) to assess the relative and absolute importance of abundance and biomass of picocyanobacteria, picoeukaryotes and nanophytoplankton along the anthropogenic trophic gradient, and (2) to determine the main environmental factors driving the distribution of these organisms in coastal waters. Various geomorphological features (volume, size, depth) of the lagoons provided contrasting hydrological conditions (e.g. episodic or continuous freshwater discharges) which have allowed us to explore how phytoplankton communities respond and adapt to anthropogenic and climate changes in coastal ecosystems. 


\section{MATERIALS AND METHODS}

Study sites. We included 24 Mediterranean coastal lagoons from the Languedoc-Roussillon region (southern French Mediterranean coast) and from Corsica (Fig. 1). Depending on the lagoon geomorphology (surface and depth), 1 to 4 stations were sampled (Table 1). Eight lagoons, named the 'Palavasian' series (Table 1), were located near the Montpellier city district (population 250 000). One site (Sea station, Fig. 1), located in the Mediterranean Sea offshore of the Diana lagoon (D), was defined as 'reference marine waters'. The hydrological characteristics of the studied lagoons are described in Table 1. All stations were sampled monthly in different years between 1998 and 2002 in the framework of the Lagoon Monitoring Network (Réseau de Suivi Lagunaire). For all lagoon stations, summer sampling was also carried out once a month from June to August in 2001 (except for Corsican lagoons) and 2002. On each date, subsurface water samples were collected between 10:00 and 16:00 $\mathrm{h}$ with $2 \mathrm{l}$ polypropylene bottles. Temperature and salinity were recorded with a WTW LF 197 field sensor (precision $\pm 0.5 \%$ ). Several

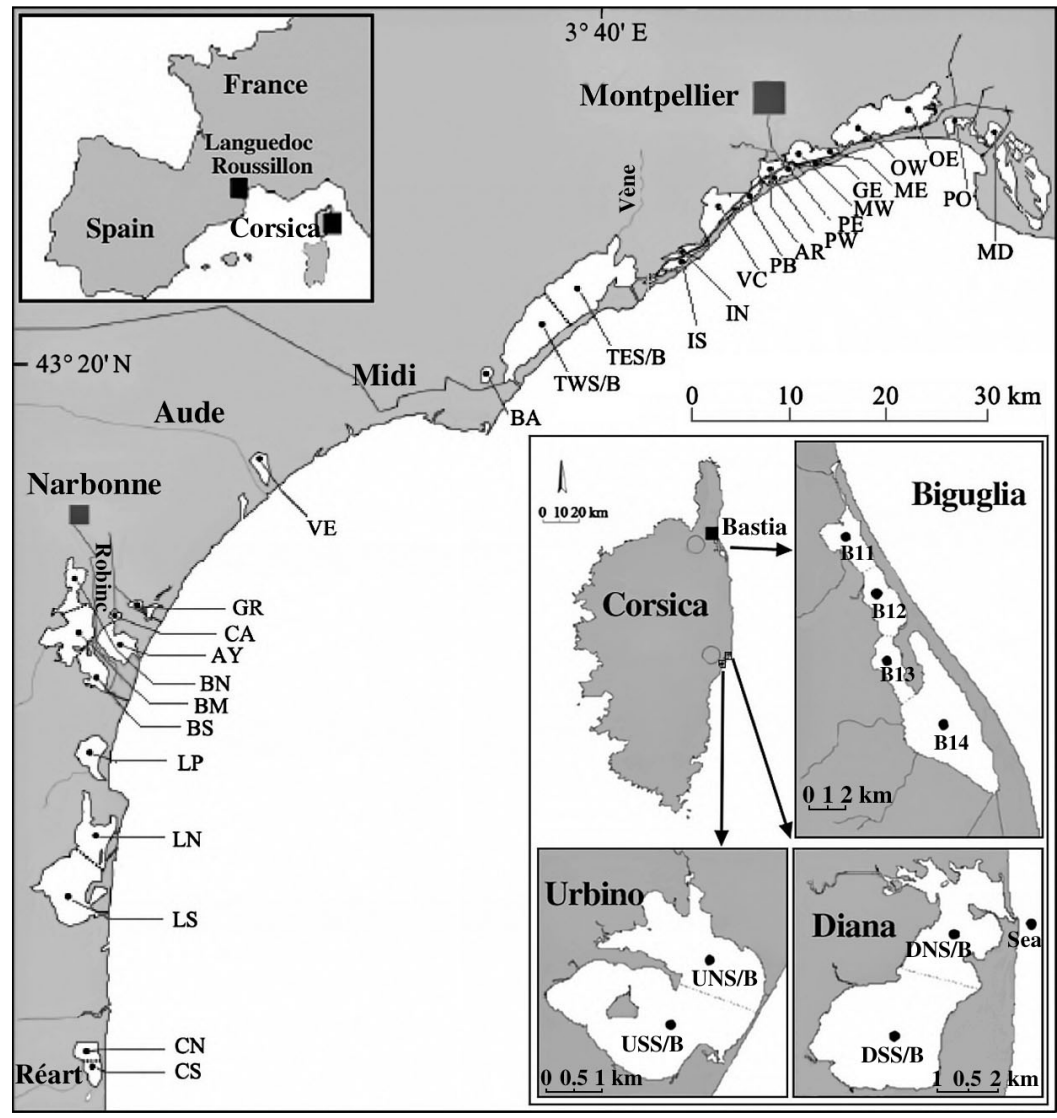

Fig. 1. The 21 lagoons along the French Mediterranean coast, the 3 lagoons in Corsica, and the Sea station offshore of the Diana lagoon with the sampling points. Table 1 gives further information on the individual stations lagoons with 2 or 4 stations (Table 1) did not exhibit significant spatial variations of salinity, leading to pooled station data for each lagoon (Lagoons C, L, T, PR, D and $\mathrm{U}_{\text {; }}$ see Table 1). We also exploited data from a nutrient database, developed by the Lagoon Monitoring Network (Souchu et al. 2010), which records concentrations of dissolved inorganic phosphorus (DIP), dissolved inorganic nitrogen (DIN $=\mathrm{NO}_{3}{ }^{+}+\mathrm{NO}_{2}{ }^{+}+\mathrm{NH}_{4}{ }^{+}$) and dissolved silicates (DSi). For each lagoon (Souchu et al. 2010), the eutrophication status was estimated according to the succession from phanerogams to macroalgae and/or phytoplankton (Schramm 1999) that has allowed us to distinguish 4 levels of trophic status (Table 1). The oligotrophic lagoons display transparent waters and a dominance of marine phanerogams with associated macroalgae. The mesotrophic state still includes climax species but also contains proliferating macroalgae. The eutrophic state leads to the disappearance of climax species, but proliferating macroalgae can still develop. Hypertrophic lagoons are characterized by quasiexclusive dominance of phytoplankton.

Phytoplankton biomass. Chlorophylls $a, b$ and $C$ (chl $a$, chl $b$ and chl $c$, respectively) and pheopigments a (phe a) were analyzed in all samples (annual cycles and additional summers). Upon return to the laboratory, 5 to $50 \mathrm{ml}$ (depending on phytoplankton abundance) were filtered under vacuum $(<10 \mathrm{~cm} \mathrm{Hg})$ on Whatman GF/F membranes $(0.7 \mu \mathrm{m}$ porosity $)$ and stored at $-20^{\circ} \mathrm{C}$ in glass tubes. Filters were ground in acetone $(90 \%)$ and extracted during $24 \mathrm{~h}$ in the dark at $4^{\circ} \mathrm{C}$. Pigments were measured by spectrofluorimetry (Neveux \& Lantoine 1993). Concentrations are expressed in $\mu \mathrm{g} \mathrm{l}^{-1}$ (precision $\pm 5 \%$ ).

Flow cytometric determination of phytoplankton abundance. A volume of $1 \mathrm{ml}$ of sample was fixed with $2 \%$ formaldehyde (final conc.) and stored in liquid nitrogen (Troussellier et al. 1995). For samples from the period 1998 to 1999 , counts were performed with an ACR-1400-SP flow cytometer (Bruker Spectrospin) fitted with a mercury-arc lamp with an excitation wavelength of 470 to $490 \mathrm{~nm}_{i}$ for counting samples from the period 2001 to 2002, we used a FACSCalibur flow cytometer (Becton Dickinson) fitted with a $15 \mathrm{~mW}$ argon laser (488 nm excitation). Samples were analyzed with a mixture of fluorescent beads ('Fluoresbrite' YG, Polysciences) of various nominal sizes 
Table 1. Morphometric and hydrological characteristics of the 24 Mediterranean coastal lagoons. For each station, median, minimum and maximum (in parentheses) values of salinity and chlorophyll a (chl a) based on annual period are indicated. Eutrophication status of each lagoon is also indicated (Souchu et al. 2010). ${ }^{*}$ Not permanently open

\begin{tabular}{|c|c|c|c|c|c|c|c|c|}
\hline $\begin{array}{r}\text { Lagoon } \\
\text { (code) }\end{array}$ & $\begin{array}{l}\text { Mean } \\
\text { depth } \\
(\mathrm{m})\end{array}$ & $\begin{array}{l}\text { Area } \\
\left(\mathrm{km}^{2}\right)\end{array}$ & $\begin{array}{l}\text { Opening } \\
\text { to the sea }\end{array}$ & $\begin{array}{l}\text { Main } \\
\text { freshwater } \\
\text { sources }\end{array}$ & Stn & Salinity & $\begin{array}{c}\text { Chl a } \\
\left(\mu g l^{-1}\right)\end{array}$ & $\begin{array}{l}\text { Trophic } \\
\text { status }\end{array}$ \\
\hline $\begin{array}{l}\text { Canet-St. Nazaire } \\
\text { (C) }\end{array}$ & 0.35 & 6.0 & Direct & River & $\begin{array}{l}\mathrm{CS} \\
\mathrm{CN}\end{array}$ & $\begin{array}{l}22.0(4.9-32.6) \\
20.4(6.2-37.8)\end{array}$ & $\begin{array}{l}19.5(3.0-204) \\
16.8(3.5-122)\end{array}$ & Hypertrophic \\
\hline Salses-Leucate (L) & 2.0 & 54 & Direct & Karst & $\begin{array}{l}\text { LS } \\
\text { LN }\end{array}$ & $\begin{array}{l}35.4(33.3-38.1) \\
37.2(34.0-40.3)\end{array}$ & $\begin{array}{l}1.6(1.0-3.0) \\
1.3(0.5-3.4)\end{array}$ & Oligotrophic \\
\hline La Palme (LP) & 0.5 & 6.0 & Direct & Karst & LP & $37.0(30.2-41.2)$ & $1.6(0.4-3.4)$ & Oligotrophic \\
\hline Bages-Sigean (B) & 1.3 & 37 & Direct & Channel & $\begin{array}{l}\text { BS } \\
\text { BM } \\
\text { BN }\end{array}$ & $\begin{array}{l}37.7(31.9-39.7) \\
34.7(29.4-40.7) \\
32.7(28.2-37.5)\end{array}$ & $\begin{array}{l}1.6(0.6-6.2) \\
2.7(0.8-23.6) \\
4.8(0.8-20.1)\end{array}$ & $\begin{array}{c}\text { Oligotrophic } \\
\text { Mesotrophic } \\
\text { Eutrophic }\end{array}$ \\
\hline Campignol (CA) & 0.5 & 1.1 & Lagoon & Channel & $\mathrm{CA}$ & $12.8(2.5-24.8)$ & $5.6(2.3-27.7)$ & Hypertrophic \\
\hline Ayrolle (AY) & 0.5 & 13.2 & Direct & Lagoon & $\mathrm{AY}$ & $35.3(20.6-38.1)$ & $1.1(0.2-4.8)$ & Oligotrophic \\
\hline Gruissan (GR) & 0.5 & 1.4 & Channel & Channel & GR & $35.7(17.8-44.0)$ & $1.6(0.3-24.5)$ & Mesotrophic \\
\hline Vendres (VE) & 0.9 & $4.8-10$ & Channel* $^{*}$ & Wetland & $\mathrm{VE}$ & $23.7(21.7-35.2)$ & $189(55-402)$ & Hypertrophic \\
\hline Bagnas (BA) & 0.4 & 1.5 & - & Wetland & BA & $5.2(0.6-18.3)$ & $7.6(1.5-119)$ & Hypertrophic \\
\hline Thau (T) & 4.0 & 75 & Direct & River & $\begin{array}{l}\text { TWS } \\
\text { TWB } \\
\text { TES } \\
\text { TEB }\end{array}$ & $\begin{array}{l}38.8(36.4-40.2) \\
38.9(36.6-40.2) \\
38.7(36.7-39.9) \\
38.7(37.0-40.0)\end{array}$ & $\begin{array}{l}1.0(0.4-7.2) \\
1.1(0.4-7.1) \\
2.3(0.4-6.9) \\
1.6(0.6-6.1)\end{array}$ & Mesotrophic \\
\hline $\begin{array}{l}\text { Palavasian lagoons } \\
\text { South-Ingril (IS) }\end{array}$ & 0.6 & 3.6 & Direct & Channel & IS & $36.1(28.7-40.0)$ & $4.7(0.7-20.5)$ & Mesotrophic \\
\hline North-Ingril (IN) & 0.6 & 3.2 & Channel & Channel & IN & $35.6(23.4-39.8)$ & $9.4(0.9-27.7)$ & Mesotrophic \\
\hline Pierre-Blanche (PB) & 0.4 & 3.7 & Channel & Channel & $\mathrm{PB}$ & $29.7(17.4-45.1)$ & $30.6(4.9-56.8)$ & Eutrophic \\
\hline $\operatorname{Vic}(\mathrm{VC})$ & 1.2 & 11.5 & Channel & Channel & $\mathrm{VC}$ & $29.4(19.3-46.4)$ & $39.7(3.1-71.7)$ & Eutrophic \\
\hline Prévost (PR) & 0.75 & 3.8 & Direct & Channel & $\begin{array}{l}\text { PRW } \\
\text { PRE }\end{array}$ & $\begin{array}{l}31.5(14.7-40.8) \\
33.9(21.8-39.3)\end{array}$ & $\begin{array}{r}15(1.8-77.6) \\
15.5(1.1-79.5)\end{array}$ & Eutrophic \\
\hline Arnel (AR) & 0.4 & 4.7 & Channel & River & AR & $29.8(7.8-40.0)$ & $16.4(2.5-310)$ & Hypertrophic \\
\hline Méjean (M) & 0.75 & 5.5 & Channel & Channel & $\begin{array}{l}\text { MW } \\
\text { ME }\end{array}$ & $\begin{array}{l}19.7(12.1-32.4) \\
22.1(12.2-32.5)\end{array}$ & $\begin{array}{l}170(57-630) \\
64.3(14.0-377)\end{array}$ & Hypertrophic \\
\hline Grec (GE) & 0.3 & 2.7 & Channel & Channel & GE & $26.8(12.1-32.7)$ & $72.9(12.6-206)$ & Hypertrophic \\
\hline Or $(\mathrm{O})$ & 0.8 & 32 & Channel & Wetland & $\begin{array}{l}\text { OW } \\
\text { OE }\end{array}$ & $\begin{array}{l}24.6(20.6-26.5) \\
22.1(18.0-24.5)\end{array}$ & $\begin{array}{l}56.1(3.0-84.9) \\
17.6(4.8-85.7)\end{array}$ & Hypertrophic \\
\hline Ponant (PO) & 2.7 & 2.0 & Direct & River & $\mathrm{PO}$ & $18.7(0.5-30.4)$ & $11.4(1.5-22.3)$ & Eutrophic \\
\hline Médard (MD) & 0.6 & 1.4 & Channel & Channel & $\mathrm{MD}$ & $20.0(15.6-23.4)$ & $8.6(1.0-86.4)$ & Eutrophic \\
\hline $\begin{array}{l}\text { Corsica } \\
\text { Biguglia (BI) }\end{array}$ & 1.5 & 14.5 & Direct* & Wetland & $\begin{array}{l}\text { BI1 } \\
\text { BI2 } \\
\text { BI3 } \\
\text { BI4 }\end{array}$ & $\begin{array}{l}20.0(14.0-37.1) \\
17.8(13.2-33.1) \\
16.8(12.6-29.5) \\
15.0(11.5-29.3)\end{array}$ & $\begin{array}{l}5.0(1.0-37.7) \\
4.4(0.9-77.1) \\
4.1(1.4-70.6) \\
3.9(2.0-30.2)\end{array}$ & Mesotrophic \\
\hline Diana (D) & 6.0 & 5.7 & Direct & River & $\begin{array}{l}\text { DSS } \\
\text { DSB } \\
\text { DNS } \\
\text { DNB }\end{array}$ & $\begin{array}{l}37.5(35.1-39.1) \\
37.9(36.0-38.9) \\
37.3(35.5-38.6) \\
37.8(36.0-39.0)\end{array}$ & $\begin{array}{l}3.2(1.1-9.4) \\
3.1(0.8-8.2) \\
1.6(0.7-6.5) \\
1.7(0.8-4.6)\end{array}$ & Oligotrophic \\
\hline Urbino (U) & 5.0 & 7.6 & Direct* ${ }^{*}$ & River & $\begin{array}{l}\text { USS } \\
\text { USB } \\
\text { UNS } \\
\text { UNB }\end{array}$ & $\begin{array}{l}36.6(32.8-39.6) \\
37.2(35.5-39.6) \\
36.5(33.0-39.5) \\
36.8(25.5-39.6)\end{array}$ & $\begin{array}{l}2.9(1.2-5.9) \\
3.1(1.4-5.1) \\
3.1(1.1-4.9) \\
3.1(1.3-4.6)\end{array}$ & Oligotrophic \\
\hline Mediterranean Sea & 40 & - & - & - & Sea & $37.5(36.8-38.7)$ & $0.4(0.1-1.0)$ & - \\
\hline
\end{tabular}



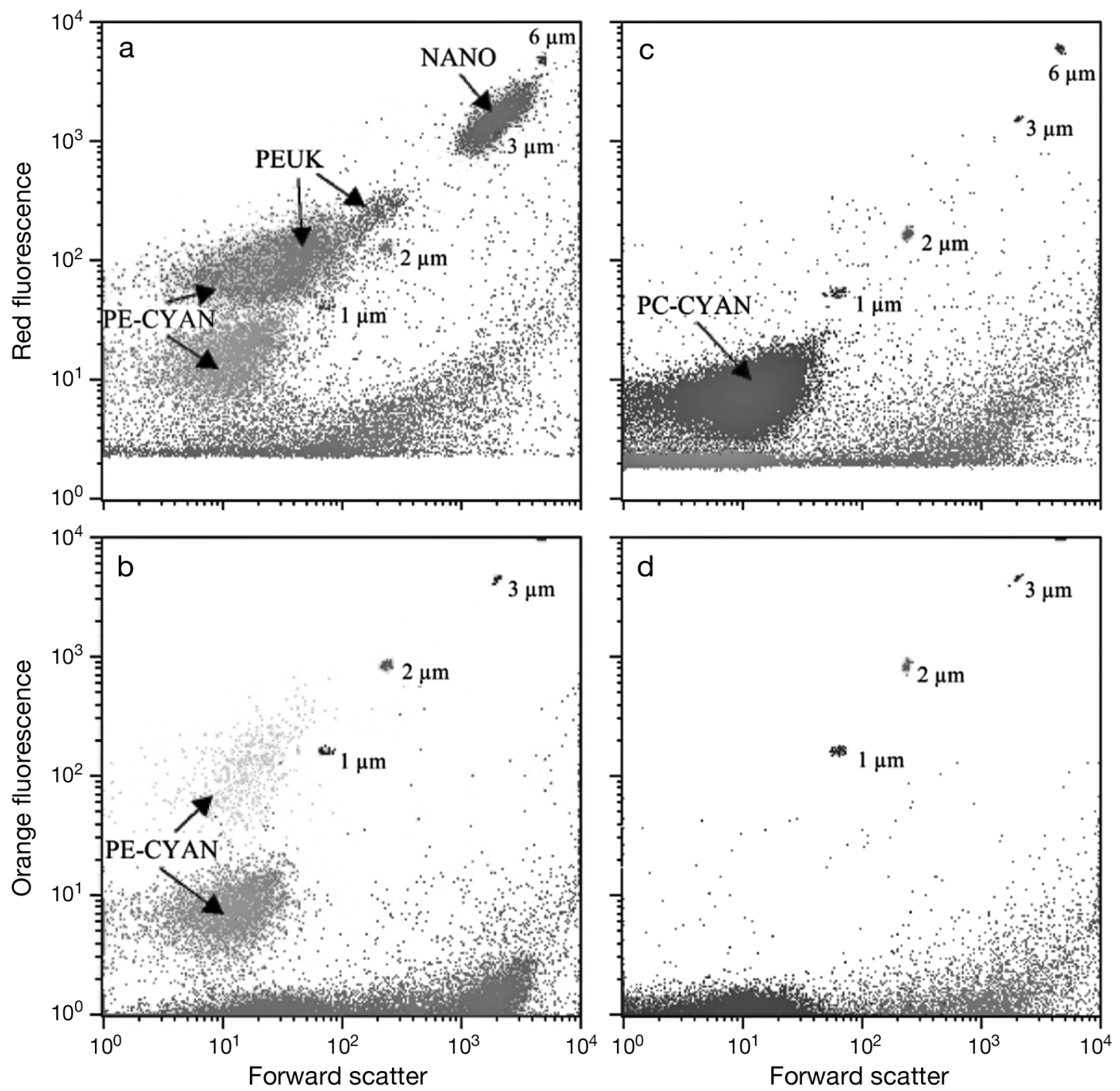

Fig. 2. Dotplots of flow cytometric analysis of phytoplankton from marine and freshwater samples collected in (a,b) Thau and (c,d) Bagnas lagoons, respectively. $(a, c)$ Forward scatter vs. red fluorescence. $(b, d)$ Forward scatter vs. orange fluorescence. These dotplots allow phycoerythrin-rich picocyanobacteria (PE-CYAN), phycocyanin-rich picocyanobacteria (PC-CYAN), autotrophic picoeukaryotes (PEUK) and nanophytoplankton (NANO) to be distinguished

$(1,2,3,6$ and $10 \mu \mathrm{m})$ to identify the size range of phytoplanktonic populations (Fig. 2). Size classes have been estimated from the average of forward scatter (FSC) values of natural populations relative to the FSC of fluorescent beads. They were also calibrated with cultures of unicellular algae whose cell diameter had been determined by optical microscopy and analyzed by Optilab Pro software (Bec et al. 2008). Cytometric analysis by size classes was carried out on data from 2001 and 2002. For sample processing, the sheath fluid was prepared from filtered (pore size $0.2 \mu \mathrm{m}$ ) artificial seawater $(\mathrm{NaCl})$ whose salinity was adjusted to that of the samples ( \pm 2 units) in order to avoid alterations of refractive indices of the cells and changes in the measured FSC (Marie et al. 1999). Two protocols have been used depending on cell size: one instrument setting for analysis of cells $\leq 3 \mu \mathrm{m}$, and another for cells $>3 \mu \mathrm{m}$. Sample acquisition was done at a flow rate of 25 to $30 \mu \mathrm{l} \mathrm{min}{ }^{-1}$. Samples were diluted when events reached $1000 \mathrm{~s}^{-1}$. Data were logged using Cell Quest software and analyzed with Attractors software (Becton Dickinson). Eukaryotic phytoplankton were distinguished on the basis of red fluorescence (FL3, related to chl $a$ fluorescence; wavelength $>650 \mathrm{~nm}$ ) and light diffraction (FSC, related to cell size). Two groups were defined depending on the cell size: $\leq 3 \mu \mathrm{m}$ (autotrophic picoeukaryotes, PEUK) and $>3 \mu \mathrm{m}$ (nanophytoplankton, NANO). Phycoerythrin-rich picocyanobacteria (PE-CYAN; Fig. 2a,b) were discriminated from other photosynthetic organisms by their strong orange fluo- 
rescence (FL2, wavelength 542 to $585 \mathrm{~nm}$ ) and lightscattering properties (FSC). The identification of phycocyanin-rich picocyanobacteria (PC-CYAN) requires a red excitation wavelength $(635 \mathrm{~nm}$; Collier 2000, Murrell \& Lores 2004). However, flow cytometers fitted with a blue laser can detect them (Collier 2000, Li \& Dickie 2001), but PC-CYAN present low red fluorescence and light-scattering characteristics very close to those of Prochlorococcus, a typical picocyanobacterium of ultra-oligotrophic ocean waters. In the present study, small $(<1 \mu \mathrm{m})$ cells with a near-background red fluorescence were detected (Fig. 2c,d) in few lagoons (Lagoons CA, BA, BI; see Table 1). Due to the hydrological characteristics of those systems (Table 1), we assumed that those were PC-CYAN rather than Prochlorococcus. Molecular analyses have confirmed the presence of PC-CYAN in those lagoons (E. Masseret unpubl. data). Thus, 4 groups (PEUK, NANO, PECYAN and PC-CYAN) were distinguished by flow cytometry for the whole data set (Fig. 2).

Phytoplankton identification. The composition of NANO and microphytoplankton was determined by optical microscopy. Identification of the main phytoplankton genera was done using a Zeiss Axiolab microscope after sedimentation (Utermöhl 1958). Samples $\left(\begin{array}{ll}1 & 1\end{array}\right)$ were fixed with Lugol's solution and preserved in the dark. A total of 150 sample identifications were performed from lagoons monitored during the period 1998 to 1999 and the period 2001 to 2002. The emphasis was on identification of the phytoplankton community from lagoons with contrasting hydrological features (freshwater, brackish and marine), with recurrent cohabitation of primary producers (opportunistic macroalgae vs. phytoplankton), and with contrasting climatic events (floods or rainy periods vs. summer periods). Samples with discrepancies between chl a biomass and abundance were also examined. These identifications have allowed us to characterize the global community structure of phytoplankton in the 24 Mediterranean lagoons.

Contribution to chl a biomass. The contribution of the 4 phytoplankton groups to total chl a biomass was estimated using chlorophyll cell content from the literature. The picocyanobacterial biomass was estimated using a chlorophyll cell content of $1.4 \mathrm{fg} \mathrm{chl} \mathrm{a} \mathrm{cell}{ }^{-1}$ (Kana \& Glibert 1987). For eukaryote microalgae, the chlorophyll cell content depends on taxonomic group (Vaillancourt et al. 2004). Based on our results from microscopic observations, accessory pigment concentration (chl $b$ and chl $c$ ) and cell size, a content of $10 \mathrm{fg}$ $\mathrm{chl} a$ cell $^{-1}$ for prasinophyte picoalgae (Vaillancourt et al. 2004) and a mean content of $200 \mathrm{fg} \mathrm{chl} a$ cell $^{-1}$ for diatoms, cryptophytes and prymnesiophytes (Vaillancourt et al. 2004) were used to estimate PEUK and the NANO biomass contribution. We excluded estimated biomass values $<0.001 \mu \mathrm{g} \mathrm{chl} \mathrm{a} \mathrm{l}^{-1}$ (i.e. less than the theoretical detection limit of chlorophyll).

Statistical analysis. Statistical analyses were done with JMP 5.0.1 software. Non-parametric tests (Wilcoxon test for $\mathrm{n}=2$ and Kruskal-Wallis test for $\mathrm{n}>2$ ) were used to compare spatial variations of environmental and biological parameters in lagoons with 2 or 4 stations. Relationships between environmental parameters and biological variables were studied using Spearman's rank correlation. The relationships between the total biomass and phytoplankton abundances were described by linear regression of logtransformed values of the variables. The variance explained by the fitted models and the significance of the fit were tested by analysis of variance (Sokal \& Rohlf 1981).

\section{RESULTS}

\section{Salinity and nutrient regimes}

The lagoon waters ranged in salinity from freshwater (salinity $<1$ ), linked to high river run-off in the rainy season (Lagoon $\mathrm{PO}$; Fig. 3), to hypersaline (salinity $>40$ ) in the dry season in shallow lagoons as a result of evaporation (LP, GR; Fig. 3). Most lagoons were characterized by brackish waters (salinity $<30$ ). Among them, lagoons surrounded by wetlands (BA, VE, O; Table 1) had relatively stable salinities throughout the year. Shallow lagoons exposed regularly to large inputs of freshwater $(\mathrm{C}, \mathrm{CA}, \mathrm{AR}, \mathrm{PO}$; Table 1) pre-

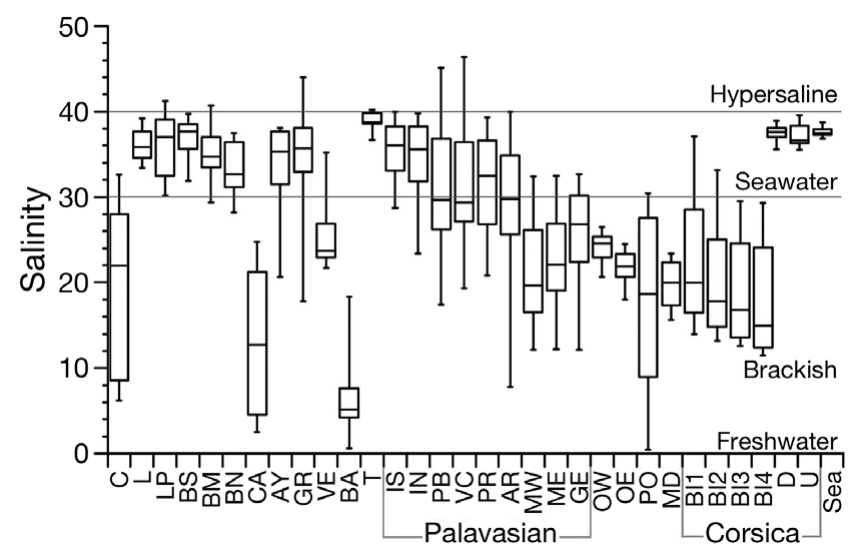

Fig. 3. Distribution of salinity in the 24 Mediterranean coastal lagoons/stations and the Sea station. Box-and-whisker plots from annual data: the whiskers represent the 5th and the 95th percentiles, the outer edges of the boxes represent the 25th and 75th percentiles, and the horizontal line within the boxes represents the median. Salinity range for hypersaline, seawater, brackish waters and freshwaters was defined as in Contreras \& Kerekes (1993). See Table 1 for station identifications and their median salinity values 
Table 2. Spearman's rank correlations between biological, physical and chemical variables at the $95 \%$ confidence interval $(\mathrm{ns}=$ not significant, $\left.{ }^{* * *} \mathrm{p}<0.001,{ }^{* *} \mathrm{p}<0.01,{ }^{*} \mathrm{p}<0.05\right)$. Correlations were computed with data from annual periods. Relatively strong correlations $(-0.50 \geq r \geq+0.50)$ are in bold. Number of data points, $n=624$. PE-CYAN = phycoerythrin-rich picocyanobacteria; PC-CYAN $=$ phycocyaninrich picocyanobacteria; PEUK = autotrophic picoeukaryotes; NANO = nanophytoplankton. Temp. = temperature $;$ DIN $=$ dissolved inorganic nitrogen; DIP = dissolved inorganic phosphorus; DSi $=$ dissolved silicates; chl $a, b, c=$ chlorophyll $a, b$ and $c$, respectively

\begin{tabular}{|c|c|c|c|c|c|c|c|c|c|c|c|c|c|}
\hline & $\operatorname{chl} a$ & $\operatorname{chl} b$ & $\operatorname{chl} C$ & PE-CYAN & PC-CYAN & PEUK & NANO & Temp. & Salinity & Turbidity & DIN & DIP & $\mathrm{DSi}$ \\
\hline Chl a & 1.00 & - & - & - & - & - & - & - & - & - & - & - & - \\
\hline Chl $b$ & $0.76^{* * *}$ & 1.00 & - & - & - & - & - & - & - & - & - & - & - \\
\hline Chl $C$ & $0.86^{* * *}$ & $0.59^{* * *}$ & 1.00 & - & - & - & - & - & - & - & - & - & - \\
\hline PE-CYAN & $0.19^{* * *}$ & $0.23^{* *}$ & $0.23^{* * *}$ & 1.00 & - & - & - & - & - & - & - & - & - \\
\hline PC-CYAN & J $0.14^{*}$ & $0.05 \mathrm{~ns}$ & $0.10 \mathrm{~ns}$ & $0.02 \mathrm{~ns}$ & 1.00 & - & - & - & - & - & - & - & - \\
\hline PEUK & $0.72^{* * *}$ & $0.67^{* * *}$ & $0.49^{* * *}$ & $0.34^{* * *}$ & $0.01 \mathrm{~ns}$ & 1.00 & - & - & - & - & - & - & - \\
\hline NANO & $0.32^{* * *}$ & $0.29^{* * *}$ & $0.45^{* * *}$ & $0.10^{* *}$ & $0.01 \mathrm{~ns}$ & $0.14^{* * *}$ & 1.00 & - & - & - & - & - & - \\
\hline Temp. & $0.14^{* * *}$ & $0.09^{*}$ & $0.18^{* * *}$ & $0.12^{*}$ & $0.17^{* *}$ & $0.11^{*}$ & $-0.01 \mathrm{~ns}$ & 1.00 & - & - & - & - & - \\
\hline Salinity & $-0.49^{* * *}$ & $-0.31^{* * *}$ & $-0.32^{* * *}$ & $-0.01 \mathrm{~ns}$ & $-0.29^{* * *}$ & $-0.33^{* * *}$ & $-0.23^{* * *}$ & $0.06 \mathrm{~ns}$ & 1.00 & - & - & - & - \\
\hline Turbidity & $0.66^{* * *}$ & $0.45^{* * *}$ & $0.48^{* * *}$ & $0.09^{*}$ & $0.04 \mathrm{~ns}$ & $0.49^{* * *}$ & $0.23^{* * *}$ & $-0.14^{* * *}$ & $-0.52^{* * *}$ & 1.00 & - & - & - \\
\hline DIN & $0.13^{* * *}$ & $0.14^{* * *}$ & $0.06 \mathrm{~ns}$ & $0.10 \mathrm{~ns}$ & $-0.07 \mathrm{~ns}$ & $0.09 \mathrm{~ns}$ & $0.24^{* * *}$ & $-0.26^{* * *}$ & $-0.48^{* * *}$ & $0.34^{* * *}$ & 1.00 & - & - \\
\hline DIP & $0.30^{* * *}$ & $0.16^{* * *}$ & $0.24^{* * *}$ & $0.00 \mathrm{~ns}$ & $0.13 \mathrm{~ns}$ & $0.05 \mathrm{~ns}$ & $0.24^{* * *}$ & $-0.01 \mathrm{~ns}$ & $-0.33^{* * *}$ & $0.33^{* * *}$ & $0.29^{* * *}$ & 1.00 & - \\
\hline DSi & $0.50^{* * *}$ & $0.47^{* * *}$ & $0.32^{* * *}$ & $0.09^{*}$ & $0.10 \mathrm{~ns}$ & $0.46^{* * *}$ & $0.11^{*}$ & $0.11^{*}$ & $-0.58^{* * *}$ & $0.35^{* * *}$ & $0.31^{* * *}$ & $0.32^{* * *}$ & 1.00 \\
\hline
\end{tabular}

sented large ranges in salinity and annual median values below 30. In contrast, deep lagoons (mean depth $>4 \mathrm{~m} ; \mathrm{T}, \mathrm{U}$ and $\mathrm{D}$ ) exhibited small ranges in salinity, with annual median values (from 36.6 to 38.9 ; Table 1) close to that observed at the Sea station (37.5).

The inverse correlation between nutrient concentrations and salinity (Table 2) indicates that nutrient loads were due mostly to freshwater discharges. Nutrient concentrations increased especially during the cold season, corresponding to the flood period in lagoons, while concentrations decreased in summer. Based on annual data, median values of DIP (dissolved inorganic phosphorus) and DIN (dissolved inorganic nitrogen) were low (0.14 and $1.3 \mu \mathrm{M}$, respectively) and $\mathrm{NH}_{4}{ }^{+}$represented the main source of DIN $(70 \%)$.

\section{Chlorophyll a gradient}

Chl a ranged from $0.2 \mu g \mathrm{l}^{-1}$ (Lagoon AY) to $630 \mu \mathrm{g} \mathrm{l}^{-1}$ (Lagoon MW) in lagoons, and from 0.1 to $1.0 \mu \mathrm{g} \mathrm{l^{-1 }}$ at the Sea station (Table 1). Large differences in annual ranges of chl a were observed between the 24 lagoons. Marine lagoons (L, T, U and D; Fig. 3) exhibited low values of chl $a$, with annual median values $<3 \mu \mathrm{g}$ chl $a$ $\mathrm{l}^{-1}$ (Table 1). In contrast, high values of chl a were measured throughout the year in shallow 'Palavasian' lagoons receiving regular effluents from the sewage treatment plants of the Montpellier city district. Lagoons exposed to high and irregular inputs of freshwater (CA and PO; Fig. 3) had relatively low annual

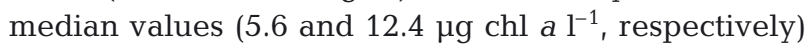
compared to 'Palavasian' series. Among hypertrophic lagoons, 2 stood out by their high levels of biomass (up to $630 \mu \mathrm{g} \mathrm{l}^{-1}$ and $400 \mu \mathrm{g} \mathrm{l}^{-1}$ in MW and VE, respectively) and highest annual median values $\left(170 \mu \mathrm{g} \mathrm{l}^{-1}\right.$ and $189 \mu \mathrm{g} \mathrm{l}^{-1}$ in MW and VE, respectively). Based on annual data, chl a was inversely correlated with salinity and was highly correlated with turbidity (Table 2).

\section{Distribution and community structure of picophytoplankton}

\section{Phycoerythrin-rich picocyanobacteria (PE-CYAN)}

PE-CYAN presented a wide range of abundances (from $10^{3}$ to $10^{8}$ cells $\mathrm{l}^{-1}$ ) that increased as total chl $a$ biomass increased, leading to a significant positive relationship between these 2 variables (Fig. 4a, Table 3). PE-CYAN were not observed in all lagoons (Fig. 5), and maximal densities were generally measured in summer. In particular, high densities (up to $2 \times 10^{8}$ cells $\mathrm{l}^{-1}$ ) were observed in summer in 3 oligotrophic marine lagoons (L, D and U; Table 1). PE-CYAN were numerically dominant only in those 3 lagoons ( $>60 \%$ of total picoplanktonic abundances; Fig. 5) but they were present in other lagoons (T, IS, PO; Fig. 5) directly connected to the sea. Summer median densities ranged between 3.8 and $6.8 \times 10^{7}$ cells $1^{-1}$ in the first ones while median values were near $1 \times 10^{7}$ cells $\mathrm{l}^{-1}$ in the latter. Blooms of PE-CYAN ( $>10^{8}$ cells $~^{-1}$ ) occurred also in lagoons presenting strong salinity variations and a large biomass of chl $a$, such as the 'Palavasian' series. However, their relative importance in terms of densities was low $(<2 \%$ of total picoplanktonic abundances; Fig. 5). Based on all lagoon data, PE-CYAN densities 

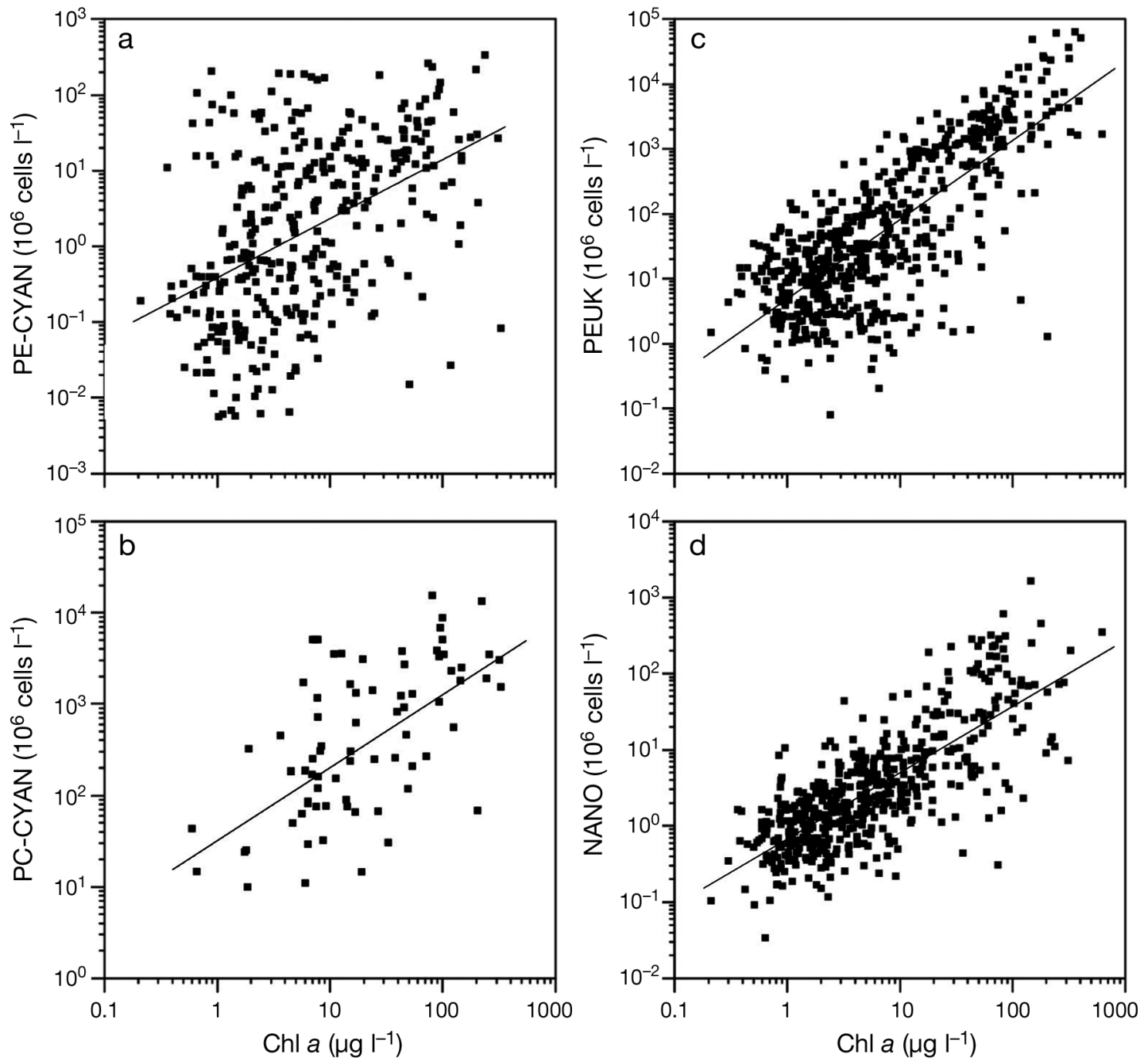

Fig. 4. Relationship between picophytoplankton and nanophytoplankton abundances $\left(10^{6}\right.$ cells $\left.\mathrm{l}^{-1}\right)$ and total phytoplankton biomass ( $\mu \mathrm{g} \mathrm{chl} \mathrm{a} \mathrm{l}^{-1}$ ) in the 24 Mediterranean coastal lagoons. (a) phycoerythrin-rich picocyanobacteria (PE-CYAN), (b) phycocyanin-rich picocyanobacteria (PC-CYAN), (c) autotrophic picoeukaryotes (PEUK) and (d) nanophytoplankton (NANO). Fitted linear regression lines are described in Table 3

were an order of magnitude lower than those of PCCYAN (Fig. 4b) and PEUK (Fig. 4c), and represented $9 \%$ of the total picoplanktonic abundance but $50 \%$ of the total abundance of picoplanktonic cells $<1 \mu \mathrm{m}$ in size. PE-CYAN densities were not significantly correlated with salinity, while other phytoplankton groups were inversely correlated with this variable (Table 2). As for the other picoplanktonic groups, PE-CYAN densities were positively correlated with temperature.

\section{Phycocyanin-rich picocyanobacteria (PC-CYAN)}

PC-CYAN presented a narrower range of abundances than did other phytoplankton groups $\left(10^{7}\right.$ to

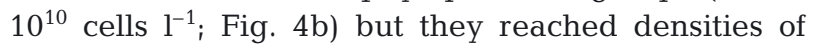

the same order of magnitude as PEUK (Fig. 4c). Their abundances increased as the total chl a biomass increased, leading to a significant positive relationship between these 2 variables (Table 3). Similar to PE-CYAN, PC-CYAN were not present in all lagoons (Fig. 5), and their abundance clearly increased in

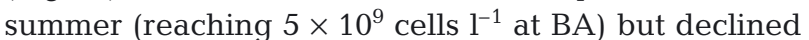
considerably in winter. They contributed $7 \%$ of the total picoplanktonic abundance and $23 \%$ of the abundance of picoplanktonic cells $<1 \mu \mathrm{m}$ in size. In summer, PC-CYAN were numerically dominant in only 2 lagoons (BI and BA; Fig. 5) characterized by brackish waters (Fig. 3). The hypertrophic wetlandlike lagoon (BA) stood out by the highest median value of PC-CYAN densities $\left(3.5 \times 10^{9}\right.$ cells $\left.\mathrm{l}^{-1}\right)$. PC-CYAN contributed significantly to the total pico- 
Table 3. Summary of relationships between total biomass ( $\mathrm{chl} a, \mu g \mathrm{l}^{-1}$ ) and phytoplankton abundances (cells $\mathrm{l}^{-1}$ ) for the 24 Mediterranean coastal lagoons. $\mathrm{PPP}=$ total picophytoplankton, $\mathrm{PEUK}=$ autotrophic picoeukaryotes, $\mathrm{PE}-\mathrm{CYAN}=$ phycoerythrin-rich picocyanobacteria, $\mathrm{PC}$-CYAN = phycocyanin-rich picocyanobacteria, NANO = nanophytoplankton. The linear model was studied, including all data sets (annual periods and additional summer data) and is represented in Figs. 4, 6 \& 7

\begin{tabular}{|c|c|c|c|c|}
\hline Fig. & Log-log regression model & $\mathrm{r}^{2}$ & $\mathrm{n}$ & $\mathrm{p}$ \\
\hline & $\log \left(\mathrm{PPP}_{\text {abund }}\right)=2.07+1.22 \log (\mathrm{chl} a)$ & 0.60 & 606 & $<0.0001$ \\
\hline $4 \mathrm{a}$ & $\log (\mathrm{PE}-\mathrm{CYAN}$ abund $)=-0.87+0.77 \log (\mathrm{chl} a)$ & 0.20 & 375 & $<0.0001$ \\
\hline $4 \mathrm{~b}$ & $\log (\mathrm{PC}-\mathrm{CYAN}$ abund $)=3.67+0.78 \log (\mathrm{chl} a)$ & 0.35 & 80 & $<0.0001$ \\
\hline $4 \mathrm{C}$ & $\log \left(\mathrm{PEUK}_{\mathrm{abund}}\right)=1.62+1.23 \log (\mathrm{chl} a)$ & 0.58 & 606 & $<0.0001$ \\
\hline $4 d$ & $\log \left(\mathrm{NANO}_{\mathrm{abund}}\right)=-0.38+0.88 \log (\mathrm{chl} a)$ & 0.58 & 530 & $<0.0001$ \\
\hline $6 a$ & $\log \left(\mathrm{PE}-\mathrm{CYAN}_{\mathrm{chl}}\right)=-3.47+0.01 \log (\operatorname{chl} a)$ & 0.00 & 156 & 0.87 \\
\hline $6 b$ & $\log \left(\mathrm{PC}-\mathrm{CYAN}_{\mathrm{chl} a}\right)=-2.90+0.78 \log (\mathrm{chl} a)$ & 0.35 & 80 & $<0.0001$ \\
\hline $6 c$ & $\log \left(\operatorname{PEUK}_{\mathrm{chl} a}\right)=-2.91+1.21 \log (\mathrm{chl} a)$ & 0.59 & 600 & $<0.0001$ \\
\hline $6 \mathrm{~d}$ & $\log \left(\mathrm{NANO}_{\mathrm{chl} a}\right)=-2.00+0.88 \log (\operatorname{chl} a)$ & 0.59 & 530 & $<0.0001$ \\
\hline $7 a$ & $\log \left(\%\right.$ PE-CYAN $\left.{ }_{\text {chl } a}\right)=1.13-0.99 \log (\operatorname{chl} a)$ & 0.66 & 156 & $<0.0001$ \\
\hline $7 \mathrm{~b}$ & $\log \left(\% \mathrm{PC}-\mathrm{CYAN}_{\mathrm{chl} a}\right)=1.71-0.22 \log (\mathrm{chl} a)$ & 0.04 & 80 & 0.07 \\
\hline $7 \mathrm{c}$ & $\log \left(\% \mathrm{PEUK}_{\mathrm{chl} a}\right)=1.67+0.22 \log (\operatorname{chl} a)$ & 0.05 & 600 & 0.0001 \\
\hline $7 d$ & $\log \left(\% N_{A N O} \operatorname{chl}_{a}\right)=2.61-0.12 \log (\mathrm{chl} a)$ & 0.04 & 530 & $<0.0001$ \\
\hline
\end{tabular}

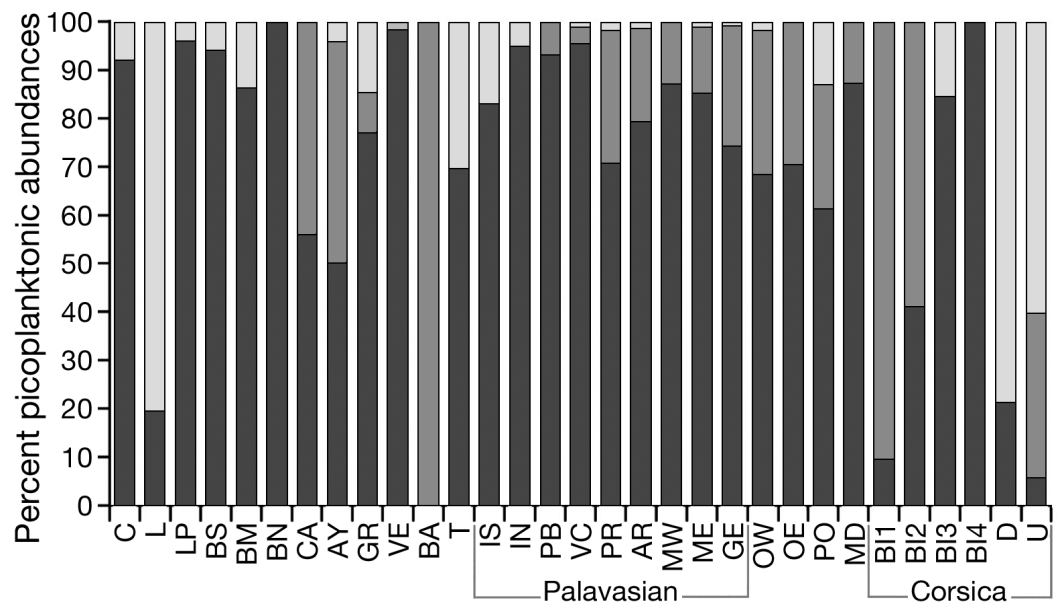

Fig. 5. Relative contribution of picocyanobacteria and autotrophic picoeukaryotes to total picoplanktonic abundances in summer in the 24 Mediterranean coastal lagoons (see Table 1). Phycoerythrin-rich picocyanobacteria (light-grey bars), phycocyanin-rich picocyanobacteria (medium-grey bars) and autotrophic picoeukaryotes (dark-grey bars)

planktonic abundance in lagoons exposed to continuous inputs of freshwater (25 to $40 \%$ in CA and $\mathrm{PO}_{i}$ Fig. 5) or eutrophic and hypertrophic lagoons such the 'Palavasian' series and the Or lagoon (15 to $30 \%$; Fig. 5). Based on annual data, blooms of PC-CYAN often occurred after floods when minimum salinities were reached in lagoonal waters. All of these observations were strengthened by correlations showing that PC-CYAN densities were positively correlated to temperature and inversely correlated to salinity (Table 2). Nevertheless, PC-CYAN could also contribute significantly to the autotrophic picoplank- ton community in oligotrophic marine lagoons (U and AY; Table 1, Fig. 5).

\section{Autotrophic picoeukaryotes (PEUK)}

PEUK presented the widest range of abundances, from $10^{5}$ to $10^{10}$ cells $\mathrm{l}^{-1}$ (Fig. 4c) and showed a significant positive relationship with total chl a biomass (Table 3). They were repeatedly observed in all lagoons and dominated the picoplanktonic community with a contribution of $84 \%$ of total abundances. Except for oligotrophic marine lagoons (L, D and U; Fig. 5) and wetland-like lagoons (BA and $\mathrm{BI}_{\text {; Fig. 5), }}$ where PE-CYAN and PC-CYAN, respectively, were dominant, the PEUK were numerically dominant in all other lagoons (Fig. 5). Extremely high densities $\left(6.4 \times 10^{10}\right.$ cells $\left.\mathrm{l}^{-1}\right)$ were observed in the summer in a hypertrophic lagoon where chl a was above $55 \mu \mathrm{g} \mathrm{l}^{-1}$ throughout the year (VE; Table 1). In this lagoon, PEUK densities were higher than in other lagoons by an order of magnitude (summer median value: $2.6 \times 10^{10}$ cells $\mathrm{l}^{-1}$ ). In other eutrophic and hypertrophic lagoons ('Palavasian' series; Table 1), median abundances ranged from 1.8 to $47 \times 10^{8}$ cells $\mathrm{l}^{-1}$ in summer. In many lagoons, PEUK abundances increased with chl $b$, as in the VE lagoon, which stood out with high values of chl $b$ (up to $83 \mu \mathrm{g} \mathrm{l}^{-1}$ ) and undetectable values of chl $C$ for most of the year. A strong positive correlation was observed between PEUK abundances and chl $b$ (Table 2). In other lagoons, PEUK increases also coincided with chl $C$ increases. Among the 4 phytoplankton groups, PEUK densities were the most strongly correlated to turbidity (Table 2). The PEUK community was numerically represented by cells of the $2-3 \mu \mathrm{m}$ size class (59\% of total picoeukaryote densities). This size class was dominant in eutrophic lagoons ('Palavasian' series) and was composed mainly of Nannochloris and Chlorella-like green algae. Picoeukaryotes belonging to the $<1 \mu \mathrm{m}$ and the 1-2 $\mu \mathrm{m}$ classes represented 16 and $25 \%$ of total PEUK densities, respectively. These size classes were observed along the eutrophication gradient. In the lagoon (VE) where record PEUK densities were observed, the picoeukary- 
ote size was $>2 \mu \mathrm{m}$. The smallest picoeukaryotes $(<1 \mu \mathrm{m})$ were dominant in oligo-mesotrophic marine waters ( $T$ and $\mathrm{D}_{i}$ Fig. 3), with summer median abundances of an order magnitude of $1 \times 10^{7}$ cells l $^{-1}$.

\section{Distribution and community structure of nanophytoplankton and microphytoplankton}

\author{
Nanophytoplankton (NANO)
}

NANO abundances were lower than those of PEUK and PC-CYAN by 2 or 3 orders of magnitude, but were near those of PE-CYAN (Fig. 4a,d). NANO densities showed a significant positive relationship with total chl a biomass (Table 3). NANO abundances were negatively correlated to salinity and, in contrast to picoplanktonic groups, were positively correlated to concentrations of DIN and DIP (Table 2). Typically, NANO expanded after floods that induced a nutrient increase in lagoonal waters in the cold season. Thus, the highest densities were generally observed in lagoons under freshwater influence ('Palavasian' series). NANO numerically dominated the phytoplankton community in only 1 shallow lagoon subjected to

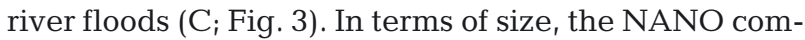
munity was numerically dominated by the 3-6 $\mu \mathrm{m}$ size class ( $49 \%$ of NANO abundances) composed mainly of centric and pennate diatoms, and various phytoflagellates (cryptophytes, chrysophytes, prymnesiophytes). NANO abundances were positively correlated with chl $c$ and chl $b$ (Table 2). The 6-10 $\mu \mathrm{m}$ and $>10 \mu \mathrm{m}$ size classes represented 29 and $22 \%$ of NANO abundances, respectively. Freshwater taxa such as Scenedesmus, Monoraphidium (chlorophytes) and Trachelomonas (euglenophytes) were observed in a lagoon (CA) subjected to permanent freshwater inputs.

\section{Microphytoplankton}

In a way similar to the NANO, microphytoplankton, composed mainly of chain-forming diatoms (Chaetoceros, Rhizosolenia, Pseudo-Nitzschia), were observed after inputs of freshwater following rain events on the watersheds in oligo-mesotrophic lagoons (GR, BS and $\mathrm{T}_{i}$ Table 1). In these lagoons, dinoflagellates (Prorocentrum, Dinophysis and Gymnodinium) appeared, in general, in summer after the spring diatom blooms. On the contrary, in oligotrophic marine lagoons, dinoflagellates dominated throughout the year, as in Lagoons U (Dinophysis, Ceratium), D (Prorocentrum) and L (Prorocentrum, Dinophysis). A particularly confined lagoon (BI) stood out by a biomass dominance of chainforming diatoms (Chaetoceros, Nitzschia) all year round. In addition, filamentous Cyanobacteria were sporadically observed in lagoons exposed to continuous inputs of freshwaters (Anabaena and Spirulina in $\mathrm{PO}$ and $\mathrm{CA}$, respectively) and in the wetland-like lagoon (Gloeotrichia in BA).

\section{Contribution of the phytoplankton community to chl a biomass}

In order to assess the relative contribution of the different phytoplankton groups to biomass, in more quantitative terms, abundances were converted to chl a (see 'Materials and methods') and were compared to total chl a biomass. The estimated biomass of PE-CYAN was lower than that of other groups

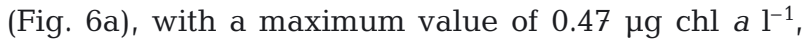
and was not related to total chl a biomass (Table 3). By contrast, the estimated chl a biomass reached 22 $\mu \mathrm{g} \mathrm{l}^{-1}$ for PC-CYAN (Fig. 6b), $144 \mu \mathrm{g} \mathrm{l}^{-1}$ for NANO (Fig. 6d) and $402 \mathrm{\mu g} \mathrm{l}^{-1}$ for PEUK (Fig. 6c). For these groups, there was a significant positive relationship between estimated chl a biomass and observed total chl a biomass (Table 3). The relative contribution of PE-CYAN and PC-CYAN to total chl a biomass reached $34 \%$ (Fig. 7a) and $100 \%$ (Fig. 7b), respectively. These maximum values were observed in summer in a marine lagoon $\left(\mathrm{L}_{1}<1 \mu \mathrm{g} \mathrm{chl} \mathrm{a} \mathrm{^{-1 }}\right)$ and a wet-

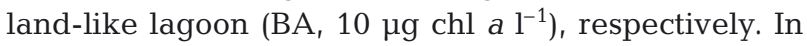
the latter, the contribution of PC-CYAN to biomass was particularly high $(>40 \%)$, except during partial lagoon drying, when it fell to $2.7 \%$. Overall, the relative contribution of picocyanobacteria tended to decrease as total chl a biomass increased, but the relationship was significant only for PE-CYAN (Table 3). Among eukaryotic algae, the relative contribution of NANO (Fig. 7d) decreased while the relative contribution of PEUK to total chl a biomass (Fig. 7c) tended to increase as total chl a biomass increased. For both, the contribution to biomass could reach $100 \%$. In the lagoon where record PEUK abundances were observed (VE), these picoalgae could contribute from 80 to $100 \%$ of total chl a biomass. Other phototrophic organisms could sporadically contribute to total chl a biomass. The highest measured biomass $(630 \mu \mathrm{g} \mathrm{chl} \mathrm{a}$ $\mathrm{l}^{-1}$ ) was related to the presence of filamentous Cyanobacteria that lead to a marked drop in the contribution of picoplankton and nanoplanktonic to total chl a biomass. In shallow lagoons, partial dry-up, caused by evaporation, could favor the resuspension of microphytobenthos (cyanobacteria or diatoms) because of the reduced water depth - leading to an exceptional increase of chl $a$ in the water column and, consequently, a decrease in the relative contribution of phytoplankton biomass. 

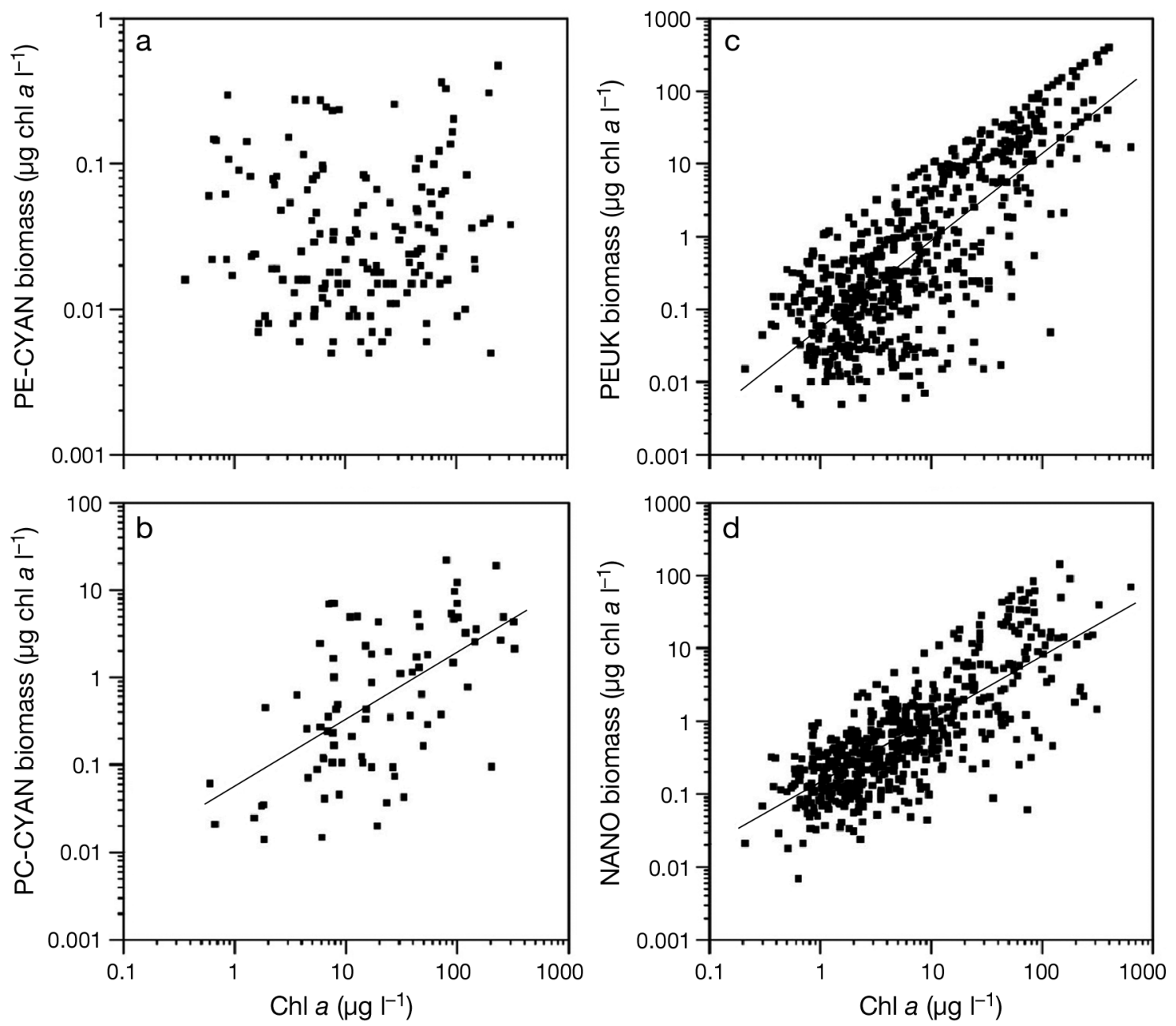

Fig. 6. Relationship between picophytoplankton and nanophytoplankton biomass $\left(\mu \mathrm{g} \mathrm{chl} \mathrm{a}^{-1}\right)$ to total phytoplankton biomass $(\mu \mathrm{g}$ chl a $\mathrm{l}^{-1}$ ) in the 24 Mediterranean coastal lagoons. (a) Phycoerythrin-rich picocyanobacteria (PE-CYAN), (b) phycocyanin-rich picocyanobacteria (PC-CYAN), (c) autotrophic picoeukaryotes (PEUK) and (d) nanophytoplankton (NANO). Fitted linear regression lines are described in Table 3

\section{DISCUSSION}

\section{Phytoplankton community structure along the trophic chl a gradient}

The 24 Mediterranean coastal lagoons present a wide range of chl a biomass $\left(0.21\right.$ to $\left.630 \mu \mathrm{g} \mathrm{l}^{-1}\right)$, varying from values reported for oligotrophic Mediterranean coastal waters (Thingstad et al. 1998) to those for hypertrophic lakes (Vörös et al. 1998, Bell \& Kalff 2001). This wide range reflects the variability in the amplitude of the nutrient enrichment and efficiency of assimilating nutrients into phytoplankton biomass (Cloern \& Jassby 2008). In the lagoons, nutrients are efficiently converted into planktonic primary producers, particularly during the warm season in which maximum chl a biomass leads to low nutrient concentrations due to continuous uptake of nutrients by massive phytoplankton blooms. In the cold season, light and temperature limitation induces a reduction in biomass, and consequently, an accumulation of nutrients that is particularly high when floods occur. Picoplanktonic abundances exhibit a seasonality similar to total chl a biomass. The temperature-dependence of growth and density of PE-CYAN (Agawin et al. 1998, Murrell \& Lores 2004, Collos et al. 2009) and PEUK (Bec et al. 2005) has been demonstrated. However, the relative and absolute importance of prokaryotic and eukaryotic autotrophic components, in terms of abundance and biomass, differ along the trophic gradient of lagoonal waters.

\section{PE-CYAN and PC-CYAN}

The abundance of picocyanobacteria significantly increases with increasing total chl a biomass. Maxi- 

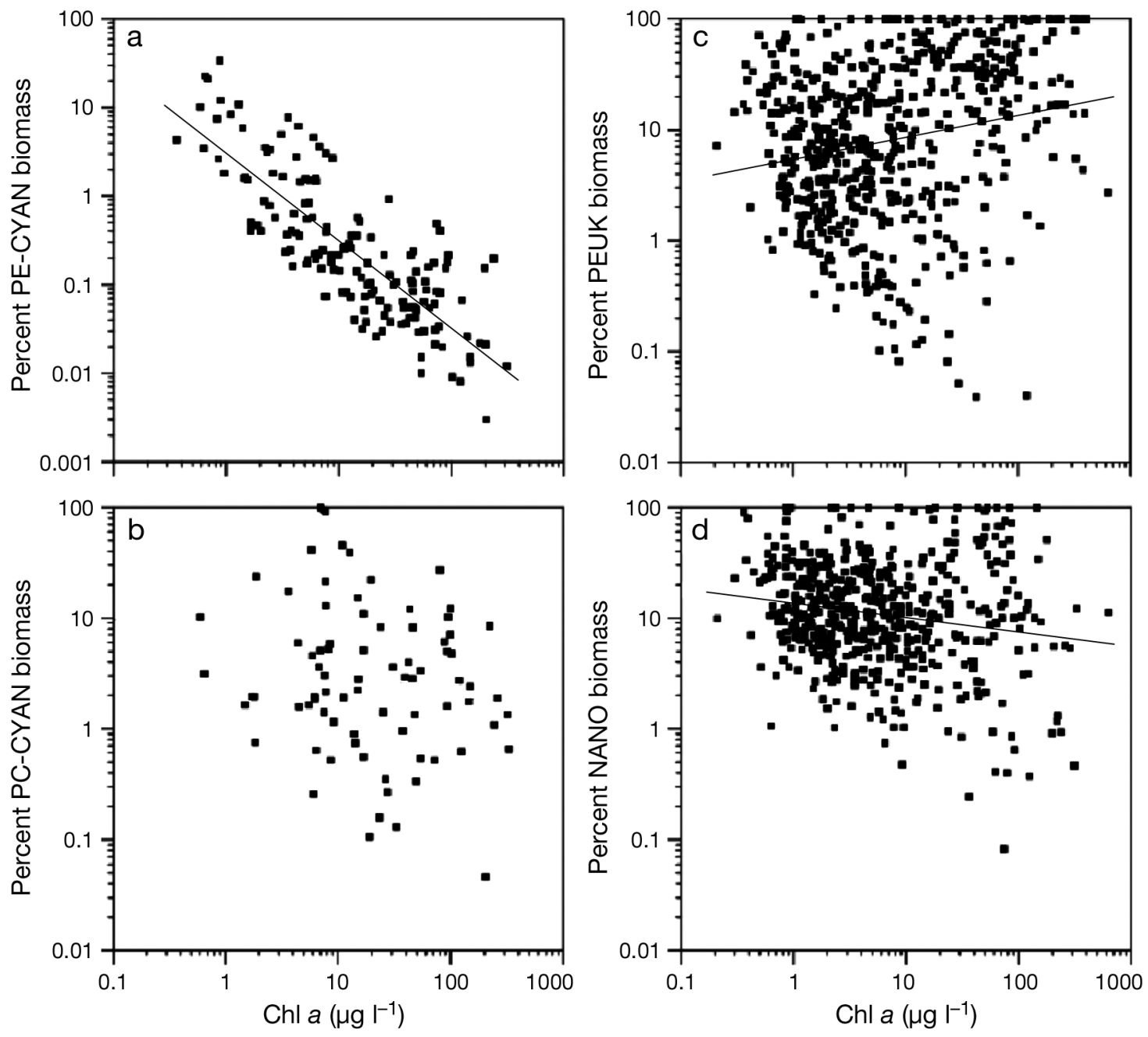

Fig. 7. Relationship between the percentage contribution of picophytoplankton and nanophytoplankton to total phytoplankton biomass $\left(\mu \mathrm{g} \mathrm{chl} \mathrm{a} \mathrm{l}^{-1}\right.$ ) in the 24 Mediterranean coastal lagoons. (a) Phycoerythrin-rich picocyanobacteria (PE-CYAN), (b) phycocyanin-rich picocyanobacteria (PC-CYAN), (c) autotrophic picoeukaryotes (PEUK) and (d) nanophytoplankton (NANO). Fitted linear regression lines are described in Table 3

mum abundances of PE-CYAN $\left(3 \times 10^{8}\right.$ cells $\left.\mathrm{l}^{-1}\right)$ and PC-CYAN $\left(5 \times 10^{9}\right.$ cells $\left.\mathrm{l}^{-1}\right)$ are close to maxima observed in lagoonal and estuarine systems (Caroppo 2000, Ning et al. 2000) and in hypertrophic lakes (Camacho et al. 2003), respectively. The numerical dominance of PE-CYAN is restricted to marine oligo-

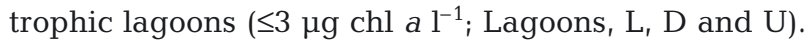
Because of their small size and high surface-to-volume ratios, these picocyanobacteria appear to be more competitive than PEUK and the larger phytoplankton in acquiring nutrients in resource-limited systems (Raven 1986, Weisse 1993). The numerical dominance of PE-CYAN can thus reflect oligo-mesotrophic conditions in marine coastal waters (Jacquet et al. 1998, Caroppo 2000, Gin et al. 2003). This dominance could be related to the ability of PE-CYAN, such as Synechococcus, to acquire phosphorus $(\mathrm{P})$ when concentra- tions are very low (Collos et al. 2009 and references therein) because $\mathrm{P}$ is the limiting nutrient in the oligotrophic lagoons where PE-CYAN dominate (Souchu et al. 2010). Conversely, the numerical dominance of PC-CYAN observed in brackish lagoons is consistent with previous studies showing their predominance in estuarine and freshwater systems (Pick 1991, Camacho et al. 2003, Murrell \& Lores 2004). In terms of chl $a$, the decreasing contribution of the 2 types of picocyanobacteria to total biomass along the trophic gradient (Fig. 7a,b) supports the conclusions drawn for marine systems (Agawin et al. 2000, Bell \& Kalff 2001) and freshwater systems (Takamura \& Nojiri 1994, Callieri \& Stockner 2002). The maximum chl a contribution of PE-CYAN observed in summer in an oligotrophic lagoon $(34 \%$; Lagoon L) confirms that their relative importance is greatest in warm and nutrient-poor 
waters of oceanic and coastal zones (Agawin et al. 2000, Collos et al. 2009). In contrast, the large contribution of PC-CYAN to biomass (up to $100 \%$ ) observed in a hypertrophic wetland-like lagoon (BA) tends to stand out from the general trend. A similar pattern of PCCYAN dominance $(>90 \%$ ) has been observed in the Pensacola Bay estuarine system (Murrell \& Lores 2004). The large contribution of PC-CYAN in these systems could be controlled by factors other than nutrient availability and/or temperature (Agawin et al. 2000).

\section{Eukaryotic algae}

The abundance of PEUK increases along the anthropogenic trophic gradient. PEUK are numerically dominant in most lagoons, contrasting with many coastal waters (Jacquet et al. 1998, Grégori et al. 2001, Gin et al. 2003). Their abundance ranges from values reported in Mediterranean coastal waters $\left(10^{6}\right.$ to $10^{7}$ cells $1^{-1}$; Jacquet et al. 1998 , Grégori et al. 2001) to values similar to those measured in hypertrophic freshwater lakes $\left(>10^{9}\right.$ cells $1^{-1}$; Hepperle \& Krienitz 2001). To our knowledge, the record densities $\left(>10^{10}\right.$ cells $\mathrm{l}^{-1}$ ) measured in the most hypertrophic lagoon (VE) have never been observed in other aquatic systems. Along the trophic gradient, PEUK become numerically dominant in mesotrophic lagoons

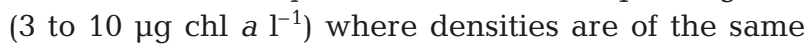
order of magnitude as those previously measured in the Thau lagoon $\left(10^{7}\right.$ to $10^{8}$ cells $\mathrm{l}^{-1}$; Vaquer et al. 1996, Bec et al. 2005). This numerical dominance could be explained by the growth capacities of PEUK - which have growth rates higher than those of picocyanobacteria (Bec et al. 2005). With increasing $N$ and $\mathrm{P}$ loads, the difference in size between eukaryotic picoplankton (ca. 2 to $3 \mu \mathrm{m}$ ) and prokaryotic picoplankton (ca. $1 \mu \mathrm{m}$ ) could favor nutrient uptake by PEUK (Raven 1986, Weisse 1993). This PEUK size class exhibits the highest growth rates (up to $3.3 \mathrm{~d}^{-1}$ ) within the ultraphytoplankton $(<10 \mu \mathrm{m})$ under both nutrient sufficiency and deficiency (Bec et al. 2008), and appears particularly adapted to steady-state nutrient conditions in most lagoons. In terms of size, dense PEUK blooms are represented mainly by small chlorophytes (2 to $3 \mu \mathrm{m}$ ) in eutrophic and hypertrophic lagoons, while smaller PEUK $(<1 \mu \mathrm{m})$ are restricted to marine oligo-mesotrophic lagoons ( $U$ and $\mathrm{T})$. In the Thau lagoon $(\mathrm{T})$, the picophytoplankton is dominated by Ostreococcus tauri (Prasinophyte), the smallest-known autotrophic eukaryote (Courties et al. 1994). These results show that the size-dependence of nutrient acquisition could shape the phytoplankton size structure even among the PEUK community.
Continued nutrient uptake by massive blooms of PEUK can lead to permanent nutrient exhaustion, particularly in summer, preventing the development of larger microalgae (Sorokin et al. 1996). This is reinforced by the relative contribution of PEUK and NANO to total chl a biomass (increasing and decreasing trend, respectively) with increasing trophic status of lagoons (Fig. 7). For the PEUK fraction, these results contrast with the general trend of many marine and freshwater systems (Agawin et al. 2000, Bell \& Kalff 2001, Callieri \& Stockner 2002). An especially important contribution of the PEUK $(>80 \%$ of total chl a biomass) is estimated here in hypertrophic lagoons, whereas the contribution of the picophytoplankton to the phytoplankton biomass is generally reduced in hypertrophic systems (Takamura \& Nojiri 1994, Sommaruga \& Robarts 1997). A similar result is observed in hypertrophic freshwater lakes where PEUK numerically dominate (Hepperle \& Krienitz 2001). NANO are decreasingly important as lagoon eutrophication proceeds, similarly to freshwater lakes (Masson et al. 2000). The growth of large phytoplankton $(>3 \mu \mathrm{m})$ is strongly regulated by nutrient availability (Chisholm 1992, Bec et al. 2005). The relative importance of NANO increases in lagoon waters when these microalgae are released from the limitation of nutrient diffusion (e.g. allochthonous nutrient pulses). As reported in productive estuarine systems (Gobler et al. 2002), the large phytoplankton (>3 $\mu \mathrm{m})$ are dominated in terms of abundance and biomass (B. Bec unpubl. data) by small diatoms and phytoflagellates (ca. 3 to $6 \mu \mathrm{m}$ ), particularly in eutrophic and hypertrophic lagoons. The pulses of $\mathrm{NH}_{4}{ }^{+}$, the major source of DIN entering lagoons from sewage treatment plants (Souchu et al. 2010), could also favor the significance of small eukaryotic algae because PEUK (Boutière et al. 1982, Gobler et al. 2002) and NANO (Collos et al. 2003, Wafar et al. 2004) have the ability to use, and generally prefer, reduced forms of nitrogen for growth. Rain events may support chain-forming diatom blooms in oligo- and mesotrophic lagoons (L, T, GR, BS) where PEUK abundances are restrained. Microphytoplankton are the main contributor to total chl a biomass in these lagoons (Collos et al. 2003, Bec et al. 2005).

\section{Influence of freshwater discharge}

In coastal waters, freshwater inputs can affect hydrological conditions, salinity and nutrient availability that alter phytoplankton biomass and community structure (Phlips et al. 2002, Puigserver et al. 2002, Paerl et al. 2003). Lagoons exposed to large and continuous inputs of freshwater (CA and $\mathrm{PO}$ ) were distinguished by par- 
tial consumption of nutrients and reduced phytoplankton biomass. Repeated periods of instability of the water column in systems exposed to high tides or continuous freshwater runoff lead to a decrease in chl a biomass compared to less turbulent systems (Monbet 1992, Puigserver et al. 2002). Rapid changes in salinity could also be a stress factor for phytoplankton communities (Phlips et al. 2002). In other lagoons, long residence time (several months), due to low tidal amplitudes, could contribute to biomass accumulation and high standing crops of phytoplankton (Knopper 1994) and, in particular, to the accumulation of picoplanktonic populations (Sorokin et al. 1996, Phlips et al. 1999). Hydrological variations can also alter the phytoplankton community structure by differentially affecting taxonomic groups depending on their growth characteristics (Paerl et al. 2003). The relative importance of NANO, composed of small diatoms and phytoflagellates (ca. 3 to $6 \mu \mathrm{m}$ ), increases in shallow lagoons exposed to high nutrient loads from continuous inputs of freshwater or discontinuous floods. In contrast, dinoflagellates $(>20 \mu \mathrm{m})$ are observed mainly in deep lagoons $(>2 \mathrm{~m}$ ) typified by the greatest water-column stability and exposed to low inputs of nutrients, and harmful dinoflagellates occur particularly in oligotrophic and mesotrophic lagoons (Collos et al. 2009). A similar situation is observed in the Seto Inland Sea where Alexandrium tamarense and Karenia mikimotoi developed as nutrient levels decreased (Nishikawa et al. 2010). As the development of harmful dinoflagellates also occurred in nutrient-enriched conditions (Anderson et al. 2002, Brand \& Compton 2007), other variables must play a role in such blooms. Water instability and pulsed inputs of nutrients related to high river discharge favor fast-growing phytoplankton (Margalef 1978) such as diatoms, chlorophytes and cryptophytes (Paerl et al. 2003). In contrast, slowergrowing organisms such as dinoflagellates are better adapted under low-nutrient, low-turbulence conditions (Margalef 1978). In brackish lagoons, the periodic development of filamentous or colonial cyanobacteria (Spirulina, Anabaena and Gloeotrichia) could be favored by reduced flushing and large inputs of nutrients (Paerl et al. 2003). These cyanobacterial blooms are often symptomatic of eutrophication of freshwaters as well as estuaries and coastal lagoons subjected to large nutrient loads (Knopper 1994).

\section{Influence of salinity}

The 24 coastal lagoons exhibit a large salinity gradient that partly drives the dynamics of 2 types of picocyanobacteria. PC-CYAN are sporadically observed, except for a wetland-like lagoon (BA) that stands out by its low salinity $(<5)$ and massive PC-CYAN blooms

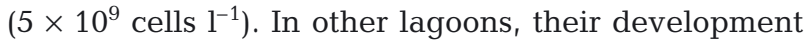
coincides with decreases in salinity (salinity range: 6 to 20) following floods. PC-CYAN are commonly observed in freshwater and estuarine systems (Vörös et al. 1998, Collier 2000) where their distribution and contribution to the picoplankton community have often been associated with a salinity gradient (Tamigneaux et al. 1995, Robineau et al. 1999, Murrell \& Lores 2004). In estuaries, a shift in dominance from PE-CYAN to PC-CYAN is observed for a salinity below 20 to 25 (Robineau et al. 1999, Murrell \& Lores 2004). PECYAN numerically dominate the picoplanktonic community only in deep marine lagoons (L, D and U) presenting low annual salinity variations and salinities close to that of the Mediterranean Sea. Strong variations in salinity in other lagoons (e.g. the 'Palavasian' series) do not prevent their development, but maximum densities remain 10 to 40 times lower than PEUK densities. These results point out the ubiquity and resilience of picocyanobacteria and suggest the presence of different strains that are physiologically adapted to lagoonal environmental conditions.

\section{Influence of underwater light quality}

The distribution of the 2 types of picocyanobacteria in lagoons could be due to physiological adaptations to other factors co-varying with salinity (Murrell \& Lores 2004). In particular, their distribution patterns could be driven by the underwater light field (Stomp et al. 2007). PE-CYAN dominate in marine oligotrophic lagoons whereas high densities of PC-CYAN are observed in brackish and hypertrophic lagoons. PE-CYAN strongly absorb radiation of wavelengths between 500 and $575 \mathrm{~nm}$ and are thus better adapted than other cyanobacteria (PC-CYAN or the genus Prochlorococcus) to benefit from green light in coastal waters (Kirk 1994, Stomp et al. 2007). This leads to their predominance within the picoplankton community in clear waters where concentrations of suspended particles and dissolved organic matter are low (Tamigneaux et al. 1995, Vörös et al. 1998, Gin et al. 2003). In contrast, PC-CYAN strongly absorb radiation of wavelengths between 600 and $650 \mathrm{~nm}$ (Kirk 1994, Stomp et al. 2007) and are well adapted to freshwater and coastal marine systems where the spectral light quality is altered (from green to red) by turbid waters that are loaded with dissolved and particulate organic matter or rich in chlorophyll (Vörös et al. 1998, Camacho et al. 2003). As a consequence, the shift from PE-CYAN dominance in lagoons characterized by low turbidity and low chl a $\left(<3 \mu \mathrm{g} \mathrm{chl} \mathrm{a}^{-1}\right)$ to PC-CYAN dominance in waters rich in chl a $\left(>30 \mu \mathrm{g} \mathrm{chl} \mathrm{a} \mathrm{l}^{-1}\right)$ could be driven by a high attenuation of light and a change in 
the underwater light quality along the trophic gradient (Pick 1991, Vörös et al. 1998). Nevertheless, PC-CYAN and PE-CYAN co-occur in low-chl a lagoons under marine influence (U, AY and GR) as well as in brackish turbid waters (the 'Palavasian' series), as observed in estuarine and coastal systems (Robineau et al. 1999, Murrell \& Lores 2004, Haverkamp et al. 2008) and freshwater lakes (Vörös et al. 1998, Mózes et al. 2006).

In summary, the wide anthropogenic and salinity gradients observed in 24 Mediterranean coastal lagoons showed that picocyanobacteria, PEUK and NANO respond differently to environmental perturbations (nutrients, salinity), and that nutrient availability is a major factor in structuring the communities. The cell size is a key morphological trait that impacts nutrient acquisition and growth, and finally shapes the structure of the phytoplankton community, even in the picoplanktonic cell range. Steady-state nutrient conditions observed in most eutrophic and hypertrophic lagoons resulted in the dominance of small eukaryotic algae. PEUK belonging mainly to the upper picoplanktonic size limit (ca. 2 to $3 \mu \mathrm{m}$ ) are the most competitive group among pico- and nanophytoplankton. Their relative importance, in terms of abundance and biomass, generally increases with increasing trophic status, contrasting with the general trend of many marine and freshwater systems. These results confirm that PEUK are able to thrive in coastal ecosystems, not only in oligo-mesotrophic marine waters but also in eutrophic and hypertrophic brackish waters.

Acknowledgements. This paper uses data from the Lagoon Monitoring Network (Réseau de Suivi Lagunaire) funded by Agence de l'Eau, Région Languedoc-Roussillon and Ifremer. Data from Corsican lagoons were supported by Office de l'Environnement de la Corse (Grant 98/162) and Interreg France-Italy project (Grant 98/474). We thank the staff of the Ifremer laboratories in Corsica and Languedoc-Roussillon, the Parc Naturel Régional de la Narbonnaise and the Réserve Naturelle de Biguglia for data collection. The authors are grateful to anonymous reviewers for their comments on the manuscript. We also thank W. K. W. Li for help in flow cytograms analysis and V. H. Smith for comments on earlier versions of this manuscript.

\section{LITERATURE CITED}

Agawin NSR, Duarte CM, Agusti S (1998) Growth and abundance of Synechococcus sp. in a Mediterranean Bay: seasonality and relationship with temperature. Mar Ecol Prog Ser 170:45-53

Agawin NSR, Duarte CM, Agusti S (2000) Nutrient and temperature control of the contribution of picoplankton to phytoplankton biomass and production. Limnol Oceanogr 45:591-600

Anderson DA, Glibert PM, Burkholder JM (2002) Harmful algal blooms and eutrophication: nutrient sources, composition, and consequences. Estuaries 25:704-726
Bec B, Husseini-Ratrema J, Collos Y, Souchu P, Vaquer A (2005) Phytoplankton seasonal dynamics in a Mediterranean coastal lagoon: emphasis on the picoeukaryote community. J Plankton Res 27:881-894

Bec B, Collos Y, Vaquer A, Mouillot D, Souchu P (2008) Growth rate peaks at intermediate cell size in marine photosynthetic picoeukaryotes. Limnol Oceanogr 53: 863-867

Bell T, Kalff J (2001) The contribution of picophytoplankton in marine and freshwater systems of different trophic status and depth. Limnol Oceanogr 46:1243-1248

Boutière $H$, de Bovée F, Delille D, Fiala M and others (1982) Effect of a dystrophic crisis in the Salses-Leucate lagoon. Oceanol Acta Actes Symp Int sur les lagunes côtières, SCOR/IABO/UNESCO, Bordeaux, 8-14 September 1981:231-242

Brand LE, Compton A (2007) Long-term increase in Karenia brevis abundance along the Southwest Florida coast. Harmful Algae 6:232-252

Callieri C, Stockner J (2002) Freshwater autotrophic picoplankton: a review. J Limnol 61:1-14

Calvo-Díaz A, Morán XAG (2006) Seasonal dynamics of picoplankton in shelf waters of the southern Bay of Biscay. Aquat Microb Ecol 42:159-174

Camacho A, Miracle MR, Vicente E (2003) Which factors determine the abundance and distribution of picocyanobacteria in inland waters? A comparison among different types of lakes and ponds. Arch Hydrobiol 157: $321-338$

Caroppo C (2000) The contribution of picophytoplankton to community structure in a Mediterranean brackish environment. J Plankton Res 22:381-397

Chisholm SW (1992) Phytoplankton size. In: Falkowski PG, Woodhead AD (eds) Primary productivity and biogeochemical cycles in the sea. Plenum Press, New York, NY, p 213-237

Cloern JE, Jassby AD (2008) Complex seasonal patterns of primary producers at the land-sea interface. Ecol Lett 11: 1294-1303

Collier JL (2000) Flow cytometry and the single cell in phycology. J Phycol 36:628-644

Collos Y, Vaquer A, Bibent B, Souchu P, Slawyk G, Garcia N (2003) Response of coastal phytoplankton to ammonium and nitrate pulses: seasonal variations of nitrogen uptake and regeneration. Aquat Ecol 37:227-236

Collos Y, Bec B, Jauzein C, Abadie E and others (2009) Oligotrophication and emergence of picocyanobacteria and a toxic dinoflagllate in Thau lagoon, southern France. J Sea Res 61:68-75

Contreras F, Kerekes J (1993) Total phosphorus-chlorophyll relationship in tropical coastal lagoons in Mexico. Verh Int Ver Limnol 25:448-451

> Courties C, Vaquer A, Troussellier M, Lautier J and others (1994) Smallest eukaryotic organism. Nature 370:255

> Gin KYH, Zhang S, Lee YK (2003) Phytoplankton community structure in Singapore's coastal waters using HPLC pigment analysis and flow cytometry. J Plankton Res 25: 1507-1519

Glibert PM, Boyer JN, Heil CA, Madden C, Sturgis B, Wazniak CS (2010) Blooms in lagoons: different from those of river-dominated estuaries. In: Kennish M, Paerl H (eds) Coastal lagoons: critical habitats of environmental change. CRC Press, Boca Raton, FL

> Gobler CJ, Renaghan MJ, Buck NJ (2002) Impacts of nutrients and grazing mortality on the abundance of Aureococcus anophagefferens during a New York brown tide bloom. Limnol Oceanogr 47:129-141 
Grégori G, Colosimo A, Denis M (2001) Phytoplankton group dynamics in the Bay of Marseilles during a 2-year survey based on analytical flow cytometry. Cytometry 44:247-256

Haverkamp T, Acinas SG, Doeleman M, Stomp M, Huisman J, Stal LJ (2008) Diversity and phylogeny of Baltic Sea picocyanobacteria inferred from their ITS and phycobiliprotein operons. Environ Microbiol 10:174-188

Hepperle D, Krienitz L (2001) Systematics and ecology of chlorophyte picoplankton in German inland waters along a nutrient gradient. Int Rev Hydrobiol 86:269-284

Jacquet S, Lennon JF, Marie D, Vaulot D (1998) Picoplankton population dynamics in coastal waters of the northwestern Mediterranean Sea. Limnol Oceanogr 43:1916-1931

> Kana TM, Glibert PM (1987) Effect of irradiances up to 2000 $\mu \mathrm{E} \mathrm{m}^{-2} \mathrm{~s}^{-1}$ on marine Synechococcus WH7803. Deep-Sea Res 34:497-516

Kirk JTO (1994) Light and photosynthesis in aquatic ecosystems. Cambridge University Press, Cambridge

Kjerfve B (1994) Coastal lagoons. In: Kjerfve B (ed) Coastal lagoon processes. Elsevier Oceanography Series 60, Amsterdam, p 1-8

Knoppers B (1994) Aquatic primary production in coastal lagoons In: Kjerfve B (ed) Coastal lagoon processes. Elsevier Oceanography Series 60, Amsterdam, p 243-287

Legendre L, Rassoulzadegan F (1995) Plankton and nutrient dynamics in marine waters. Ophelia 41:153-172

Li WKW, Dickie PM (2001) Monitoring phytoplankton, bacterioplankton, and virioplankton in a coastal inlet (Bedford Basin) by flow cytometry. Cytometry 44:236-246

Malone TC (1980) Algal size. In: Morris I (ed) The physiological ecology of phytoplankton. Blackwell, Oxford, p 433-463

Margalef R (1978) Life-forms of phytoplankton as survival alternatives in an unstable environment. Oceanol Acta 1: 493-510

Marie D, Partensky F, Vaulot D, Brussaard C (1999) Enumeration of phytoplankton, bacteria and viruses in marines samples. In: Robinson JP, Darzynkiewicz D, Dean PN, Orfao A and others (eds) Current protocols in cytometry. John Wiley, New York, NY, p 1-15

> Masson S, Pinel-Alloul B, Smith VH (2000) Total phosphorus-chlorophyll: size fraction relationships in southern Québec lakes. Limnol Oceanogr 45:732-740

Monbet Y (1992) Control of phytoplankton biomass in estuaries: a comparative analysis of microtidal and macrotidal estuaries. Estuaries 15:563-571

Morel A, Ahn YH, Partensky F, Vaulot D, Claustre H (1993) Prochlorococcus and Synechococcus: a comparative study of their optical properties in relation to their size and pigmentation. J Sea Res 51:617-649

Mózes A, Présing M, Vörös L (2006) Seasonal dynamics of picocyanobacteria and picoeukaryotes in a large shallow lake (Laka Balaton, Hungary). Int Rev Hydrobiol 91: 38-50

- Murrell MC, Lores EM (2004) Phytoplankton and zooplankton seasonal dynamics in a subtropical estuary: importance of cyanobacteria. J Plankton Res 26:371-382

Neveux J, Lantoine F (1993) Spectrofluorimetric assay of chlorophylls and phaeopigments using the least squares approximation technique. Deep-Sea Res 40:1747-1765

Ning X, Cloern JE, Cole BE (2000) Spatial and temporal variability of picoyanobacteria Synechococcus sp. in San Francisco Bay. Limnol Oceanogr 45:695-702

> Nishikawa T, Hori Y, Nagai S, Miyahara K and others (2010) Nutrient and phytoplankton dynamics in Harima-Nada, eastern Seto Inland Sea, Japan, during a 35-year period from 1973 to 2007. Estuar Coast 33:417-427
Paerl HW, Dyble J, Moisander PH, Noble RT and others (2003) Microbial indicators of aquatic ecosystem change: current application to eutrophication studies. FEMS Microbiol Ecol 46:233-246

> Paerl HW, Valdes LM, Peierls BL, Adolf JE, Harding LW (2006) Anthropogenic and climatic influences on the eutrophication of large estuarine ecosystems. Limnol Oceanogr 51:448-462

Pan LA, Zhang J, Zhang LH (2007) Picophytoplankton, nanophytoplankton, heterotrophic bacteria and viruses in the Chanjiang Estuary and adjacent coastal waters. J Plankton Res 29:187-197

Partensky F, Blanchot J, Vaulot D (1999) Differential distribution and ecology of Prochlorococcus and Synechococcus in oceanic waters: a review. Bull Inst Oceanogr 19: 457-476

Phlips EJ, Badylak S, Lynch TC (1999) Blooms of the picoplanktonic cyanobacterium Synechococcus in Florida Bay, a subtropical inner-shelf lagoon. Limnol Oceanogr 44:1166-1175

> Phlips EJ, Badylak S, Grosskopf T (2002) Factors affecting the abundance of phytoplankton in a restricted subtropical lagoon, the Indian river lagoon, Florida, USA. Estuar Coast Shelf Sci 55:385-402

Pick FR (1991) The abundance and composition of freshwater picocyanobacteria in relation to light penetration. Limnol Oceanogr 36:1457-1462

Puigserver M, Ramon G, Moyà G, Martínez-Taberner A (2002) Planktonic chlorophyll a and eutrophication in two Mediterannean litorral systems (Mallorca Island, Spain). Hydrobiologia 475/476:493-504

Raven JA (1986) Physiological consequences of extremely small size for autotrophic organisms in the sea. In: Platt T, Li WKW (eds) Photosynthetic picoplancton. Can Bull Fish Aquat Sci 214, Fisheries and Oceans, Ottawa

> Robineau B, Legendre L, Michel C, Budeus G, Kattner G, Schneider W, Pesant S (1999) Ultraphytoplankton abundances and chlorophyll a concentrations in ice-covered waters of northern seas. J Plankton Res 21:735-755

Schramm W (1999) Factors influencing seaweed responses to eutrophication: some results from EU-project EUMAC. J Appl Phycol 11:69-78

Sokal RR, Rohlf FJ (1981) Biometry, 2nd edn. WH Freeman, San Francisco, CA

Sommaruga R, Robarts RD (1997) The significance of autotrophic and heterotrophic picoplankton in hypertrophic ecosystems. FEMS Microbiol Ecol 24:187-200

> Sorokin YI, Sorokin YP, Gnes A (1996) Structure and functioning of the anthropogenically transformed Comacchio lagoonal ecosystem (Ferrara, Italy). Mar Ecol Prog Ser 133: $57-71$

Souchu P, Bec B, Smith VH, Laugier T and others (2010) Patterns in nutrient limitation and chlorophyll $a$ along an anthropogenic eutrophication gradient in French Mediterranean coastal lagoons. Can J Fish Aquat Sci 67:743-753

Stomp M, Huisman J, Vörös L, Pick F, Laamanen M, Haverkamp T, Stal L (2007) Colourful coexistence of red an green picocyanobacteria in lakes and seas. Ecol Lett 10:290-298

Takamura N, Nojiri Y (1994) Picophytoplankton biomass in relation to lake trophic state and the TN:TP ratio of lake water in Japan. J Phycol 30:439-444

> Tamigneaux E, Vazquez E, Mingelbier M, Klein B, Legendre L (1995) Environmental control of phytoplankton assemblages in nearshore marine waters, with special emphasis on phototrophic ultraplankton. J Plankton Res 17: 1421-1447 
Thingstad TF, Zweifel UL, Rassoulzadegan F (1998) P limitation of heterotroph bacteria and phytoplankton in the northwest Mediterranean. Limnol Oceanogr 43:88-94

Troussellier M, Courties C, Zettelmaier S (1995) Flow cytometric analysis of coastal lagoon bacterioplankton and picophytoplankton: fixation and storage effects. Estuar Coast Shelf Sci 40:621-633

Utermöhl H (1958) Zur Vervollkommnung der quantitativen Phytoplankton-Methodik. Mitt Int Ver Theor Angew Limnol 9:1-38

> Vaillancourt RD, Brown CW, Guillard RRL, Balch WM (2004) Light scattering properties of marine phytoplankton: relationships to cell size, chemical composition and taxonomy. J Plankton Res 26:191-212

Vaquer A, Troussellier M, Courties C, Bibent B (1996) Standing stock and dynamics of picophytoplankton in the
Thau lagoon (northwest Mediterranean coast). Limnol Oceanogr 41:1821-1828

Vörös L, Callieri C, Balogh KV, Bertoni R (1998) Freshwater picocyanobacteria along a trophic gradient and light quality range. Hydrobiologia 369/370:117-125

- Wafar M, L'Helguen S, Raikar V, Maguer JF, Le Corre P (2004) Nitrogen uptake by size-fractionated plankton in permanently well-mixed temperate coastal waters. J Plankton Res 26:1207-1218

Weisse T (1993) Dynamics of autotrophic picoplankton in marine and freshwater ecosystems. In: Jones JG (ed) Advances in microbial ecology. Plenum Press, New York, NY, p 327-370

> Worden A, Nolan JK, Palenik B (2004) Assessing the dynamics and ecology of marine picophytoplankton: the importance of the eukaryotic component. Limnol Oceanogr 49:168-179

Submitted: July 29, 2010; Accepted: November 30, 2010 Proofs received from author(s): February 14, 2011
Editorial responsibility: Patricia Glibert, Cambridge, Maryland, USA 